\title{
Health risk assessment related to an effect of sample size fractions: methodological remarks
}

\author{
Alicja Kicińska ${ }^{1}$ (D) \\ Published online: 25 November 2017 \\ (C) The Author(s) 2017. This article is an open access publication
}

\begin{abstract}
Contents of $\mathrm{As}, \mathrm{Cd}, \mathrm{Co}, \mathrm{Cr}, \mathrm{Cu}, \mathrm{Ni}, \mathrm{Pb}$ and $\mathrm{Zn}$ were determined in the material collected in sandboxes of seven spa resorts located in S Poland (CCE) and their results used to establish a health risk of children. After sieving out grains $>2 \mathrm{~mm}$, the bulk samples were quantitatively separated into four grain fractions: 2000-1000, 1000-200, 200-63 and $<63 \mu \mathrm{m}$. In each of them were determined: the mineral composition, the total contents of the elements, and the distribution of the elements among the fractions distribution factor. In the bulk material $<2 \mathrm{~mm}$, the totals of the elements are 5-64 times lower than in the finest fractions $(<63 \mu \mathrm{m})$. Considering that the finest fractions are enriched in clay minerals such as clinochlore, illite and kaolinite, which can adsorb and desorb metals, this material is most dangerous for children, staying both permanently and temporarily in the spas. The total health risks $H I$ resulting from non-carcinogenic elements present in the fractions $<63 \mu \mathrm{m}$ are 1.26 and 0.94, for the children-residents 3 and 6 years old, respectively. The figures are disturbing as one of them exceeds and the other is close to a permissible limit of 1 . The highest contribution (93.4\%) into the total $H I$ is caused by inadvertent swallowing the soil "dirt": the ingestion path $H Q_{\text {ing }}$ for the 3 years old residents is 1.17 , and for the 6-year olds 0.88. With respect to the elements, the highest is the risk resulting from $\mathrm{Pb}: H Q_{\text {in }}$ values of the residents are 4.71E-01 and 3.54E-01 for the 3-year olds and the 6-year olds. Slightly lower are the $H Q_{\text {ing }}$ values calculated for both age groups: in the case of $\mathrm{Cr}-3.12 \mathrm{E}-01$ and $2.34 \mathrm{E}-01$ and $\mathrm{As}-2.92 \mathrm{E}-01$ and $2.19 \mathrm{E}-01)$. The dermal path $\left(H Q_{\text {dermal }}\right)$ contributes to the total $H I$ much less as it equals $6.5 \%$, while the contribution of the inhalation path $\left(H Q_{\text {inhal }}\right)$ is considerably the lowest and equals only $0.1 \%$. The Risk indexes determined in the case of cancerogenic components for both age groups of the spa residents are lower than the permissible limit $10 \mathrm{E}-5$ and equal $6.48 \mathrm{E}-06$ and $9.72 \mathrm{E}-06$, respectively. Considering the children that only visit the spas, all the calculated indexes, i.e., $H I$ and Risk, are significantly lower than those determined for the children-residents.
\end{abstract}

Keywords Grain fraction · Analytical methods · Metal variability $\cdot$ Risk assessment

\section{Introduction}

Significant factors in environmental investigations pertaining to the health risk include methods of collecting samples, their kind, number, and representativeness of the environment component considered. The issues of the chemical nature, such as the methodology and correctness

Alicja Kicińska

kicinska@geol.agh.edu.pl

1 Department of Environment Protection, Faculty of Geology, Geophysics and Environmental Protection, AGH University of Science and Technology, Mickiewicza $30 \mathrm{Av}$, 30-059 Kraków, Poland of analyses, as well as the precision and accuracy of determinations seem currently to be easy verified due to using standardized procedures and reference standards. Therefore, the magnitude of possible errors in the environmental studies depends mainly on the selection of a strategy and a procedure of sampling, the process of sampling itself, and the field determinations (Migaszewski and Galuszka 2016). They are followed by data processing, the selection of a statistical method, then the interpretation and evaluation of the results, and eventually provide final pieces of information on the state of the environment and rectifying (if necessary) steps. The reliability and precision of determinations are highly important when they refer to toxic substances present in the environment (Hlavay et al. 
1992; Gong et al. 2014; Klojzy-Karczmarczyk 2014; AlHwaiti and Al-Khashman 2015; Stala-Szlugaj 2016). Deleterious elements include heavy metals, particularly $\mathrm{Cd}, \mathrm{Pb}, \mathrm{Tl}$ and $\mathrm{As}$ (in fact, arsenic is a metalloid, but for the brevity it will be further referred to as a metal). These elements may not only affect a proper functioning of organisms, but irreversibly disturb their growth (KabataPendias and Pendias 1999; Al-Hwaiti et al. 2014; Islam et al. 2016; Taiwo et al. 2017).

A health risk caused by toxic substances is assessed using environmental samples collected in the places where children come into contact with them most often or most probably. Such sites include mainly playing grounds, sport fields, sandboxes, urban parks, gardens of nurseries and school recreational grounds (Jartun et al. 2003; Yamamoto et al. 2006; De Miguel et al. 2007; Guney et al. 2010; Wei and Yang 2010; Diatta and Grzebisz 2011; Figueiredo et al. 2011; Ak et al. 2012; Du et al. 2013; Niec et al. 2013; Kicińska 2016a; Wang et al. 2016). The collection of samples to be used for establishing a degree of ground or soil contamination and the calculating a health risk caused by metals the samples contain are controlled by various standards being in force in different countries (US EPA 1996; Ministry 2003; Minister 2016). Usually the material finer than $2 \mathrm{~mm}$ is the subject of analyses (Jartun et al. 2003; Bai et al. 2009; Marjanović et al. 2009; Guney et al. 2010; Wei and Yang 2010; Figueiredo et al. 2011; AlHwaiti et al. 2015; Dziubanek et al. 2015; Kicińska 2016b; Stajic et al. 2016), but some authors suggest analyzing other grain fractions. For instance, in the samples rich in the organic matter Boone et al. (1999) recommended a fraction with grains $<0.5 \mathrm{~mm}$. A finer fraction of $<0.1 \mathrm{~mm}$ was separated by De Miguel et al. (2007) when investigating the health risk of children in the playgrounds of Madrid. In turn, Diatta and Grzebisz (2011) concentrated on the grain fraction $<1 \mathrm{~mm}$ when analysing the quantity of metals the visitors of the urban parks of Poznań (Poland) are exposed to. The grain fractions obtained using the set of sieves 2, 0.250 and $0.125 \mathrm{~mm}$ were separated when studying (Valskys et al. 2016) the material of the playing grounds of Vilnius (Lithuania).

The dependency between the content of elements and the grain size of the analytical sample was dealt with, among others, by Ljung et al. (2006), Yamamoto et al. (2006), Ajmone-Marsan et al. (2008), Gong et al. (2014) and Kosa and Kicińska (2016). The latter authors underlined a high concentration of $\mathrm{As}, \mathrm{Cd}, \mathrm{Pb}$ and $\mathrm{Cr}$ in the finest grain fractions. Simultaneously, Yamamoto et al. (2006) established that these are soil and ground particles with the size $39 \pm 26 \mu \mathrm{m}$ that adhere best to children hands, and the total mass of such a stack "dirt" may reach even $162.5 \mathrm{mg}$ per hand. A recommendation of the United State Environmental Protection Agency (US EPA) pertaining to the evaluation of the health risk suggest accepting a soil mass of $200 \mathrm{mg}$ per day in the case of children from 1 to 6 years old, and lower this dose at least at a half in the case of adults (US EPA 1986).

Considering the said above, the investigations centered on the impact of a sampled material grain size when evaluating the health risk of children that use playing grounds of the spas recommended for youngsters in Poland (Central-Eastern Europe-CEE). In seven such spa resorts the surface (0-20 cm u.g.l.) sand material of the sandboxes was collected in 2016 and the following determinations were made:

(1) separating four grain fractions and establishing their contributions to bulk samples,

(2) establishing the mineral composition and the morphology of particles in each grain fraction,

(3) determining the quantity of selected elements in the bulk sandy material $<2 \mathrm{~mm}$ and the four grain fractions separated. The elements included are those related to road traffic $(\mathrm{Cu}, \mathrm{Zn}, \mathrm{Ni}, \mathrm{Cr}, \mathrm{Co}$ and $\mathrm{Pb})$ and to the low emission (mainly As and $\mathrm{Cd}$ ), considering them as major anthropogenic pollutants of the spa localities.

(4) calculating from the results of the steps 1-3 the health risk indexes $H I$ caused by non-cancerogenic substances and the indexes Risk caused by carcinogenic substances containing the elements specified in (3). Children are endangered by contaminants entering their organisms along three possible paths, i.e., ingesting, inhaling and skin contacting. The calculations were directed into finding any relation between sample grain sizes and the total contents of the elements considered. The most crucial aim, important for further investigations, was establishing the sample grain fraction whose analyses provide the most sound basis in the calculations of the health risk for children.

\section{Materials and methods}

\subsection{Site selection and sampling}

The investigations were carried out in seven spas of Poland (CCE): Krynica, Muszyna, Piwniczna, Rabka, Swoszowice, Szczawnica and Wysowa. Six of them are located within the Carpathians, and Swoszowice at the very margin of the hills, in the Malopolska Voivodeship administrative area (Fig. 1). The spa status was granted them in 1967, and mineral waters as their main medicinal resource. The problems of the upper and lower respiratory tracts are treated in all the spas except for Swoszowice. 


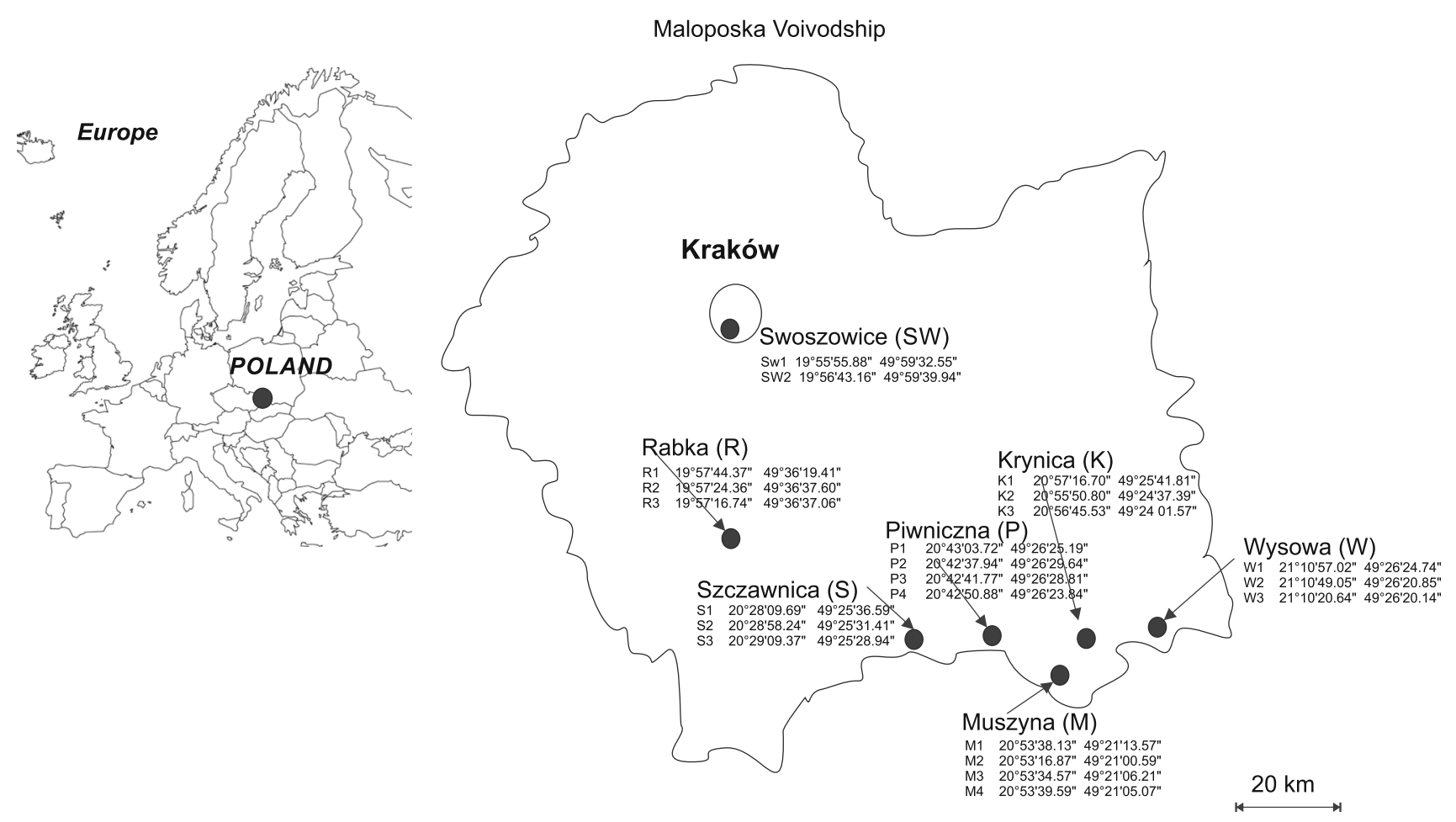

Fig. 1 Sampling sites

In each of the spas there are two to four playing grounds that contain sandboxes. The sandy material was collected in four sites within every sandbox and represented socalled general surface samples. The total of samples was 88 and a mass of each around $2 \mathrm{~kg}$.

The material collected on-site was placed into plastic bags, then dried and prepared to chemical analyses, which were conducted at the Laboratory of Trace Analyses, the Chair of Environment Protection in Cracow. The fraction above $2 \mathrm{~mm}$ was removed in the first stage and the remainders (weight $1 \pm 0.01 \mathrm{~kg}$ ) of each sample were drysieved into three grain fractions: 2000-1000 (symbol $\mathrm{F}_{2000-1000}$ ), 1000-200 (symbol $\mathrm{F}_{1000-200}$ ) and 200-63 (symbol $\left.\mathrm{F}_{200-63}\right) \mu \mathrm{m}$; the fourth, finest fraction $<63 \mu \mathrm{m}$ (symbol $\mathrm{F}_{<63}$ ) was wet-sieved. The subject of further analyses were the bulk samples $<2 \mathrm{~mm}$ and the four grain fractions separated from each of them.

The determinations of the quasi-totals of elements were made by dissolving the samples in aqua regia $\left(\mathrm{HCl}+\mathrm{HNO}_{3}\right.$, at the ratio 3:1) in a microwave oven SCP SCIENCE, DigiPREP HT type, at $130{ }^{\circ} \mathrm{C}$ and 90,100 and 110 psi ("quasi" as aqua regia does not completely decompose silicate-rich samples). The mass of the analytical samples was $0.5 \mathrm{~g}$.

The phase composition of crystalline components was carried out applying the powder Debye-Sherrer method using a Rigaku MiniFlex 600 XRD diffractometer. The measurement parameters were as follows: $\mathrm{CuK}_{\alpha}$ radiation, reflection graphitic monochromator, lamp voltage $40 \mathrm{kV}$, lamp current $20 \mathrm{~mA}$, recording range $2-72^{\circ} 2 \Theta$; step $0.05^{\circ} 2 \Theta$, impulse count rate $1 \mathrm{sek} / \mathrm{step}$. The interplanar distances obtained from the X-rays patterns were used for identifying crystalline phases based on the data of the ICDD (International Centre for Diffraction Data) catalogue and the XRAYAN software.

Optical microscopy (a Nikon Eclipse 50i-POL unit) and scanning electron microscopy SEM-EDS (a FEI Quanta model 200 FEG unit) were used for observing the morphology of the grains in all the fractions and conducting spot analyses. The observations were extended by chemical analyses of microareas applying an EDS detector (SEMEDS method) conducted in the high vacuum mode. The resolution power of the microscope was increased by covering the samples with carbon prior to analysing. The accelerating voltage was $20 \mathrm{kV}$. The mineral composition was assessed macroscopically except for the finest $\left(F_{<63}\right)$ fraction.

The chemical composition was determined using the method of induced coupled plasma mass emission spectroscopy (ICP-MS) at the certified hydrogeochemical laboratory (certificate of the Polish Accreditation Commission no. AB1050) of the AGH University of Science and Technology in Krakow. The Certipur Certified Reference Material (HC69208280) was used as a standard. The precision of the determining $\mathrm{Fe}, \mathrm{Ca}, \mathrm{Al}, \mathrm{K}, \mathrm{Mg}, \mathrm{Si}, \mathrm{Mn}, \mathrm{Na}$, 
$\mathrm{Zn}, \mathrm{Ba}, \mathrm{Pb}, \mathrm{As}, \mathrm{Ti}, \mathrm{Cd}, \mathrm{Ni}, \mathrm{Tl}, \mathrm{Cr}$ and $\mathrm{Co}$ was $10 \%$, while the accuracies (AO) ranged between 95 and $105 \%$.

The following equations were used when calculating the limits of detection LOD and quantification LOQ presented in Table 2:

$\mathrm{LOD}=\mathrm{X}_{\mathrm{b}}+3 S D_{\mathrm{b}}$,
$\mathrm{LOQ}=\mathrm{X}_{\mathrm{b}}+10 S D_{\mathrm{b}}$,

where $\mathrm{Xb}$, mean concentration of the blank (zero concentration) sample, $S D_{\mathrm{b}}$, the standard deviation of the blank sample.

The health risk $H I$ was calculated according to the US Environmental Protection Agency (US EPA 1996, 1997) procedure, accepting three pathways: $H Q_{i n g}$ - direct ingestion of substrate particles (US EPA 1986, Kicińska et al. 2017), $H Q_{i n h}$-inhalation of re-suspended particles via mouth and nose, and $H Q_{\text {dermal }}$-dermal absorption of metals from the particles adhered to an exposed skin (De Miguel et al. 2007). The health risk values: $H Q_{\text {ing }}, H Q_{\text {inhal }}$ and $\mathrm{HQ}_{\text {dermal }}$ were calculated for each element as the ratio of the contact doses $\left(\mathrm{D}_{\text {ing }}, \mathrm{D}_{\text {inhal }}\right.$, and $\mathrm{D}_{\text {dermal }}$, respectively) to the corresponding reference doses $\left(\mathrm{RfD}_{\text {ing }}, \mathrm{RfD}_{\text {inhal }}\right.$, and $\mathrm{RfD}_{\text {dermal }}$, respectively) following the US EPA (2005).

The doses $\mathrm{D}_{\text {ing }}, \mathrm{D}_{\text {inh }}$ and $\mathrm{D}_{\text {dermal }}$ were calculated using the following equations (US EPA 1986):

$$
\begin{aligned}
& \mathrm{D}_{\text {ingestion }}=C \cdot \frac{\operatorname{IngR} \cdot E F \cdot E D}{B W \cdot A T} \cdot C F 1, \\
& \mathrm{D}_{\text {inhalation }}=C \cdot \frac{\operatorname{InhR} \cdot E F \cdot E D}{P E F \cdot B W \cdot A T}, \\
& \mathrm{D}_{\text {dermal }}=C \cdot \frac{S A \cdot S L \cdot A B S \cdot E F \cdot E D}{B W \cdot A T} \cdot C F 1,
\end{aligned}
$$

where $C$, mean concentration of the metal in a sample $(\mathrm{mg} /$ $\mathrm{kg})$, IngR, conservative estimates of dust ingestion rates; for children 100 (mg per hour) (US EPA 2011), InhR, inhalation rate; in this study $1.2\left(\mathrm{~m}^{3} /\right.$ hour) (US EPA 2011), $E F$, exposure frequency; for residents accepted as 646 (hours/year) after De Miguel et al. (2007), for visitors as 84 (hours/year), $E D$, exposure duration; for younger children 3 (years) and for older ones 6 (years), $B W$, body mass; for children 3 years old $15(\mathrm{~kg})$, for those 6 years old $20(\mathrm{~kg})$ (US EPA 2011), AT, averaging time. In the case of noncarcinogens: for 3 years old children its value is 1095 (days) and for 6 years old children 2190 (days), while in the case of carcinogens the value is 25,550 (days), $S A$, exposed skin area, $2800\left(\mathrm{~cm}^{2}\right)$ after De Miguel et al. (2007), SL, skin adherence factor, $0.07\left(\mathrm{mg} / \mathrm{cm}^{2}\right.$ per hour) after De Miguel et al. (2007), ABS, dermal absorption factor, 0.001 (for all the elements except As, for which ABS is 0.03) after De Miguel et al. (2007), PEF, particle emission factor, $6.8 \mathrm{E}+08\left(\mathrm{~m}^{3} / \mathrm{kg}\right)$ after De Miguel et al. (2007), $C F 1$, unit conversion factor of $10^{-6}$.
The $H I$ index was calculated as a sum of $H Q_{i n g}, H Q_{\text {inhal }}$, and $H Q_{\text {dermal }}$ values. At $H I \leq 1$ the adverse health effects are of a low probability to occur, at $H I>1$ they are probable, while the $H I>10$ values are a sign of a high exposure and a highly possible chronic health risk caused by a toxic factor(s).

To establish a level of the cancer Risk for carcinogens, the $H Q$ doses were multiplied by the respective slope factors (US EPA 2005, for Pb WHO 1993).

The distribution of the elements considered within the grain fractions has been expressed calculating the distribution factor $\left(D F_{\mathrm{x}}\right)$. It is one of the important indexes which was used in this study to evaluate in which fraction the metals (As including) are preferentially accumulated by referring the fraction to bulk quantities (Eq. 6):

$D F_{x}=\frac{\text { Xfraction }}{\text { Xbulk }}$

where $X_{\text {fraction }}$ and $X_{\text {bulk }}$ are concentration of element (mg/ $\mathrm{kg}$ ) in the given fraction and bulk sample, respectively. If $D F_{\mathrm{x}}>1$ for the specific fraction, the element (here: metal) is enriched. Statistical calculations and data presentations were conducted with the Statistica ver. 10 and Excel applications. The differences between means were detected by the Turkey's HSD test at a significance level of 0.05 .

\section{Results and discussion}

\subsection{Grain and mineral composition of the sand samples}

The sieve analyses conducted on the set of 88 samples provide the results sufficient to compare the distribution of grain fractions in the sands of the spa sandboxes (Table 1). The arithmetical means indicate that the grains between 1000 and $200 \mu \mathrm{m}\left(\mathrm{F}_{1000-200}\right)$ are the prevailing material and make up $78.2 \mathrm{wt} \%$ on the average. The grains with sizes from 200 to $63 \mu \mathrm{m}\left(\mathrm{F}_{200-63}\right)$ are approximately 5 times less frequent and make up $18.72 \mathrm{wt} \%$. The contents of the coarsest $\left(\mathrm{F}_{2000-1000}\right)$ and finest $\left(\mathrm{F}_{<63}\right)$ grain fractions are insignificant, close in both cases to $1.5 \mathrm{wt} \%$.

Each of the fractions, if observed under the optical microscope, is composed mostly (around $90-80 \%$ ) of oval, well rounded quartz grains. They are highly transparent (Fig. 2c, e), some of them posses a delicate milky brown coloration. Minor particles are represented by black, opaque grains, possibly amphiboles and pyroxenes, and greenish grains that may be olivines. The list is supplemented by fine plates of both micas, i.e., muscovite and biotite. Some grains of the two coarsest fractions ( $F_{2000-1000}$ and $\left.F_{1000-200}\right)$ have rough, uneven surfaces and their small hollows and fractures are filled with an adhering 
Table 1 Share of sand fractions

\begin{tabular}{lcllll}
\hline Site & $\mathrm{n}$ & \multicolumn{2}{l}{ Grain size $(\mu \mathrm{m})$} \\
\cline { 3 - 6 } & \multicolumn{2}{l}{$\begin{array}{l}2000-1000 \\
\text { Share of fraction }(\%)\end{array}$} \\
\hline Szczawnica & 12 & $0.76-1.80$ & $71.48-79.56$ & $15.01-23.33$ & $1.50-2.84$ \\
Rabka & 12 & $0.07-1.34$ & $79.28-91.79$ & $6.53-15.74$ & $0.32-1.38$ \\
Krynica & 12 & $1.89-2.46$ & $64.79-75.04$ & $17.55-24.73$ & $0.78-1.67$ \\
Muszyna & 16 & $0.29-1.26$ & $63.94-79.33$ & $15.74-26.01$ & $1.04-2.43$ \\
Piwniczna & 16 & $0.49-2.33$ & $70.01-79.37$ & $15.26-27.39$ & $1.72-3.65$ \\
Wysowa & 12 & $0.42-6.01$ & $73.29-73.30$ & $16.84-23.86$ & $0.90-2.12$ \\
Swoszowice & 8 & $0.50-0.52$ & $83.65-85.18$ & $13.40-13.66$ & $0.65-0.88$ \\
For all destination & & & & & \\
min.-max. & 88 & $0.07-6.01$ & $63.94-91.79$ & $6.53-27.39$ & $0.32-3.65$ \\
Average & & 1.49 & 78.20 & 18.72 & 1.59 \\
\hline
\end{tabular}

$n$ number of samples, min. minimum, max. maximum, average arithmetic average

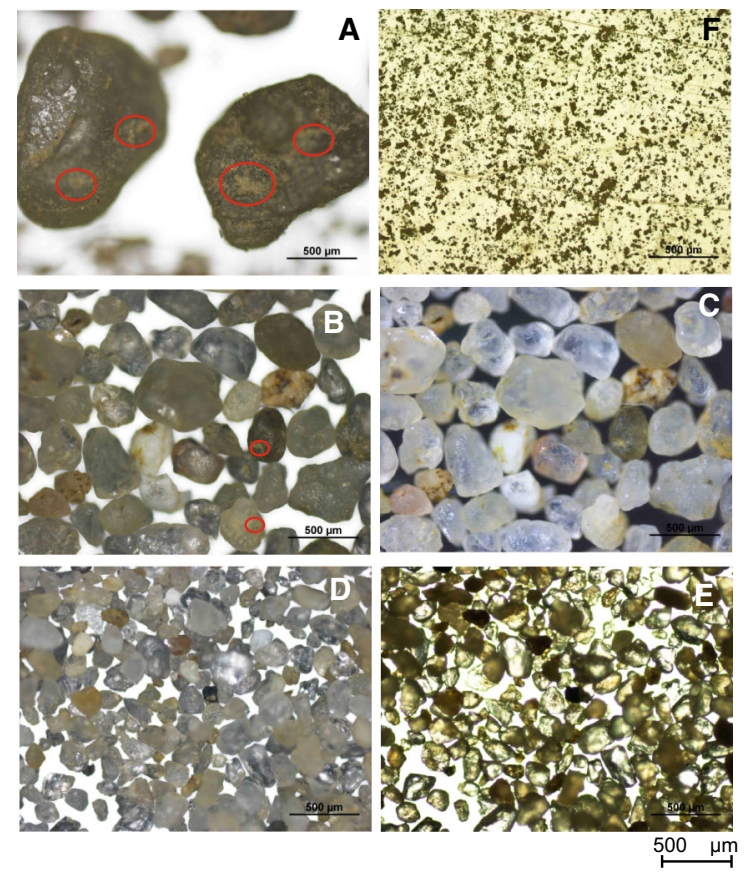

Fig. 2 Macro and transmitted plane-polarized light microscope images of the sample P3 from Piwniczna: sand fractions 2000-1000, b, c 1000-200, d, e 200-63, and f $<63 \mu \mathrm{m}$ red circle accumulation of $\mathrm{F}<63$

material (Fig. 2a, b, d). In the fraction $\mathrm{F}_{2000-1000}$ also occur grains whose surfaces are completely covered by a finegrained, usually darker material. The finest grain fraction $\mathrm{F}_{<63}$ is composed of compact, mostly pelitic aggregates, whose identification has not been possible using optical microscopy (Fig. 2f). Therefore, more sophisticated methods had to be applied, namely X-ray diffraction XRD and scanning electron microscopy SEM-EDS.

$\mathrm{X}$-ray diffraction patterns reveal that the fraction $\mathrm{F}<63$ is composed mainly of quartz $\left(\mathrm{SiO}_{2}\right)$, a mineral resistant to atmospheric and chemical factors (Fig. 3). It is accompanied by feldspars: Na-rich albite $\left(\mathrm{Na}\left[\mathrm{AlSi}_{3} \mathrm{O}_{8}\right]\right)$ of the plagioclase group, and $\mathrm{K}$-feldspar microcline $\mathrm{K}\left[\mathrm{AlSi}_{3} \mathrm{O}_{8}\right]$. Feldspars as a whole group are less resistant to weathering than quartz and within the group their potassium varieties are more resistant than plagioclases. Kaolinite $\mathrm{Al}_{4}\left[(\mathrm{OH})_{8} \mid \mathrm{Si}_{4} \mathrm{O}_{10}\right]$, belonging to the group of clay minerals and identified in some samples, may be a product of plagioclase weathering. In most of the samples tested identified amphibole-magnesioriebeckite $\mathrm{Na}_{2} \mathrm{Mg}_{3} \mathrm{Fe}_{2}{ }^{3+}[(\mathrm{OH}$, F)| $\left.\mathrm{Si}_{4} \mathrm{O}_{11}\right]_{2}$, belonging to the group of glaucophosphates (alkaline amphiboles). Muscovite $\mathrm{KAl}_{2}\left[(\mathrm{OH})_{2} \mid \mathrm{AlSi}_{3} \mathrm{O}_{10}\right]$, a dioctahedral mica, is a common, however minor or trace component of sands. This mineral is to a certain degree resistant to physical and chemical changes, but advanced weathering of sediments may transform it to hydromuscovite, while a further degradation to illite $\left(\mathrm{K}, \mathrm{H}_{3} \mathrm{O}\right) \mathrm{Al}_{2}\left[(\mathrm{OH})_{2} \mid \mathrm{AlSi}_{3} \mathrm{O}_{10}\right]$. Illite, one of the clay minerals, may also be formed by structural changes of other clay minerals. Two clay minerals, illite and clinochlore $(\mathrm{Mg}, \mathrm{Al})_{3}\left[(\mathrm{OH})_{2} \mid \mathrm{AlSi}_{3} \mathrm{O}_{10}\right] \cdot \mathrm{Mg}_{3}(\mathrm{OH})_{6}$, have been XRDidentified in traces. One of the properties of clay minerals is their adsorption of cations (Sotch 1974) due to not compensated charge of the layer units that is related to isomorphic substitutions within the tetra- and octahedral layers. Adsorption depends on (after Sotch 1974) the cation type, concentration of a solution, $\mathrm{pH}$, the presence of other cations, mineral structure, time of the exchange, temperature and the size of the mineral. Clay minerals are thus mineral substances with the highest sorption capacity of cations (Kabata-Pendias and Pendias 1999, Wardas-Lasoń 2014).

Morphological observations using the SEM-EDS method were supported by spot analyses in microareas of particles of the fraction $\mathrm{F}_{<63}$ (Figs. 4 and 5). The grains are 


\section{A}

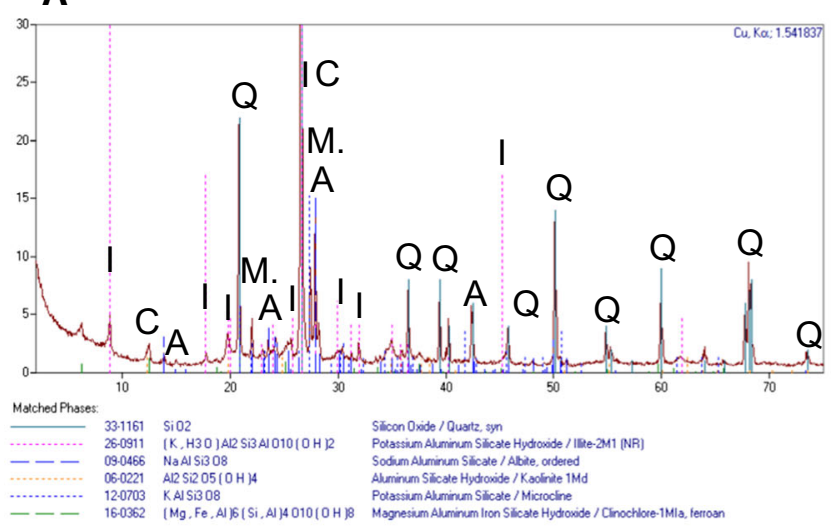

C

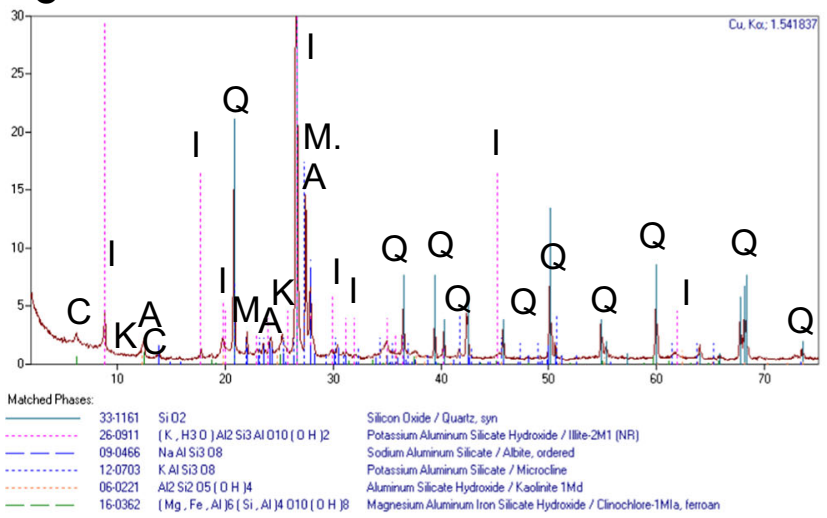

B

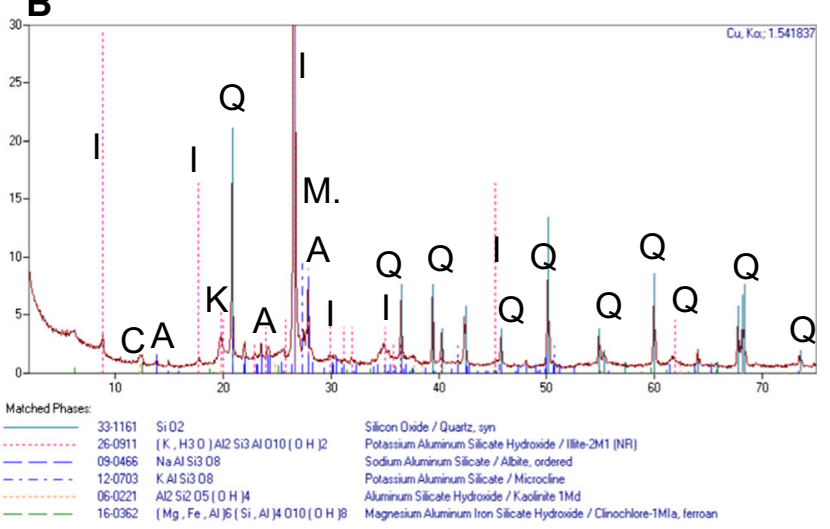

D

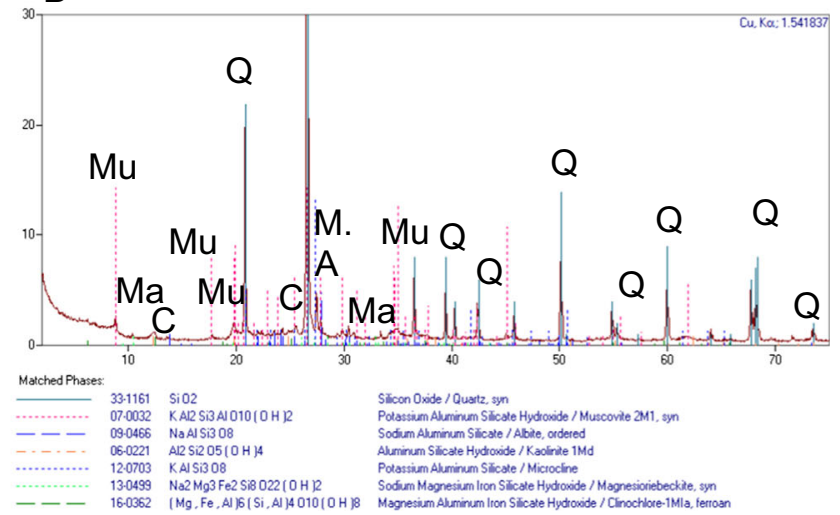

Fig. 3 XRD patterns of sand samples colectted in: a Krynica (sample no. K1), b Szczawnica (sample no. SZ2), c Piwniczna (sample no. P2), d Swoszowice (sample no. SW2). $Q$ quartz, $I$ illite, $A$ albite, $M$. microcline, $K$ kaolinite, $C$ clinochlore, $M u$ muscowite, $M a$ magnesioriebeckite

mostly irregular and jagged, with sizes from 1 to $5 \mu \mathrm{m}$ (Fig. 4a, b), some are sharp-edged and elongated, often coated with much finer material (Fig. 4a). Other grains represent larger aggregates (see central part of Fig. 4b, the size of the aggregate is $20 \times 30 \mu \mathrm{m})$, cemented with an amorphous material, being probably a $\mathrm{Ca}$ and $\mathrm{Mg}$ carbonate. The analyses of the sample collected in Krynica indicate a dominance of $\mathrm{Fe}, \mathrm{Si}, \mathrm{Pb}, \mathrm{Al}$ and $\mathrm{Sn}$ oxides (Fig. 4a). The spectrum recorded in Fig. 4b (point 1) identifies dioxides of $\mathrm{Si}$ (quartz), $\mathrm{Ti}$ (rutile) and oxides and oxy/hydroxides of $\mathrm{Fe}$ and Al. A larger, oval grain (Fig. 4c, top right corner) is probably ilmenite $\left(\mathrm{FeTiO}_{3}\right)$. The spectrum in the point 2 (Fig. $4 \mathrm{c}$ ) suggests the presence of zircon $\mathrm{Zr}\left[\mathrm{SiO}_{4}\right]$, a mineral resistant to chemical factors. Other minerals of the fraction $<63 \mu \mathrm{m}$ include clinochlore (point 3, Fig. 4c), rutile $\mathrm{TiO}_{2}$ (point 4, Fig. 4c), and beside clinochlore, other clay minerals. One of $\mathrm{Fe}$ oxides (magnetite or hematite) is shown in Fig. 4d (point 1), while probable zircon in point 2 . Figure 5 presents the morphology and chemistry of grains identified in the samples $\mathrm{F}_{<63}$ collected in Swoszowice. The grains marked 1(A) and 2(A) in Fig. 5 have been identified as chlorites (clinochlore, baileychlore?), $\mathrm{Fe}$ oxy/hydroxides, and- tentatively-as fayalite $\mathrm{Fe}_{2}{ }^{2+}\left[\mathrm{SiO}_{4}\right]$. The grains 3(A) and 1(B) in Fig. 5 contain rare earth elements (REE) and may represent monacite $(\mathrm{Ce}, \mathrm{La}, \mathrm{Th}, \mathrm{Nd}, \mathrm{Y}, \mathrm{Pr}) \mathrm{PO}_{4}$. Among the grains in samples from Szczawnica (Fig. 5c, d), an unidentified large, oval grain (diameter around $50 \mu \mathrm{m}$ ) has the uneven surface covered with a finer material (Fig. 5c, central part). The spot analyses in points $1(\mathrm{C})$ and 2(C) indicate that the coating particles are clay minerals (illite, clinochlore?). Another grain in Fig. 5d (point (D) may be a phyllosilicate (but its Ba content is strikingly high) of $12.74 \mathrm{wt} \%$ ).

\subsection{Metal contents of the sand samples}

\subsubsection{Bulk sand samples}

In the bulk samples. i.e., those without the material $>2 \mathrm{~mm}$, the average contents of the metals considered range as follows: As $0.20-3.60, \mathrm{Cd} 0.01-0.18$, Co $0.21-1.59$, Cr 2.40-6.02, Cu 0.56-2.24, Ni 1.46-5.37, Pb $0.68-5.50$ and $\mathrm{Zn} 7.59-37.92 \mathrm{mg} / \mathrm{kg}$ (Table 2). Detailed characteristics on the metal quantities and forms of metal occurrences were described separately (Kicińska et al. 

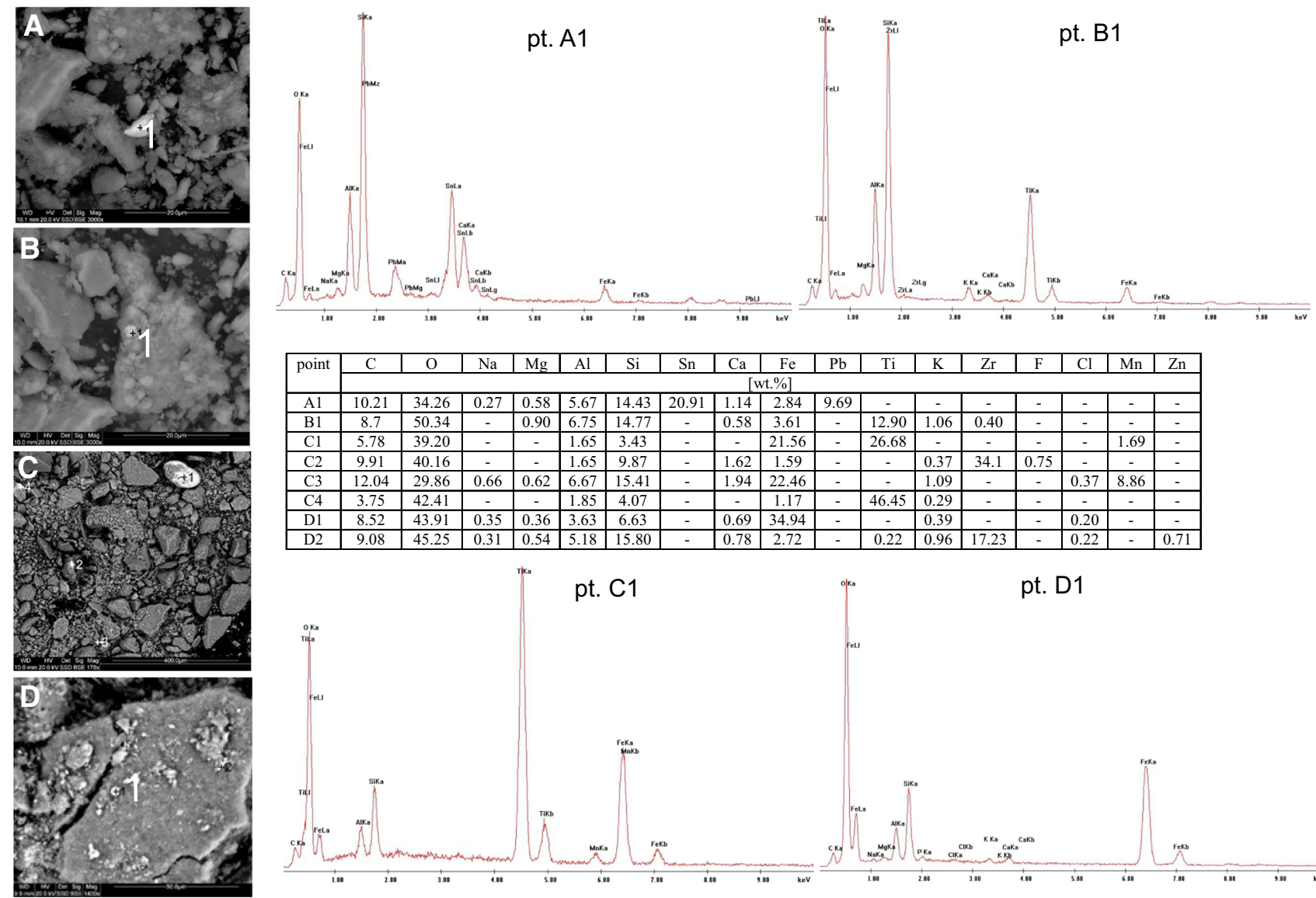

pt. C1

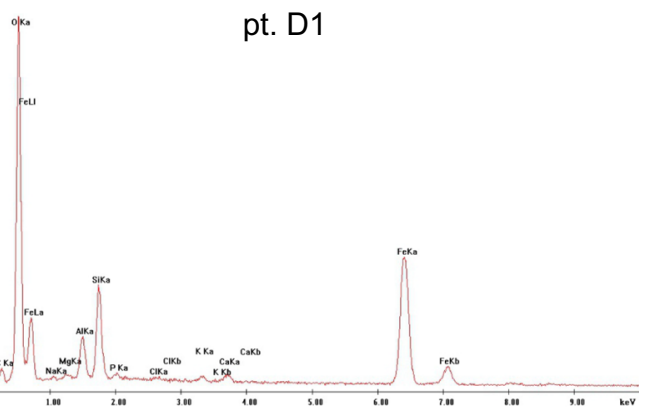

Fig. 4 SEM images and EDS spectra of sand samples F $<63 \mu \mathrm{m}$ collected in Krynica (a, b), Piwniczna (c, d), “-” not identified

2017). The quantities of $\mathrm{Cd}, \mathrm{Co}, \mathrm{Cu}, \mathrm{Pb}, \mathrm{Ni}$ and $\mathrm{Zn}$ determined here are significantly lower than those found in analogous samples in Silesia, an industrial region of Poland (Kicińska 2016a, b). Arsenic makes in the spa material a difference: it occurs in significantly higher quantities than in Silesia. The results of the analyses are lower than the legal upper limits in force in 2016, i.e., the year of sampling in the case of $\mathrm{As}, \mathrm{Cd}, \mathrm{Co}, \mathrm{Cu}, \mathrm{Ni}, \mathrm{Pb}$ and $\mathrm{Zn}$ (Minister 2002, Ministerie 2000; Alexander 2006) except for Cr. The chromium contents exceed in $36 \%$ of the spa samples a limit of $5 \mathrm{mg} \mathrm{Cr}{ }^{6+} / \mathrm{kg}$ stipulated in the Norwegian standards (Alexander 2006). This value refers to the chromium in the hexavalent form that is soluble and then becomes toxic, but in the well rain-washed sandboxes the $\mathrm{Cr}^{6+}$ quantities are insignificant and do not represent a real threat.

\subsubsection{Fractions $F_{<63}$ of the sands}

Considering all the $\mathrm{F}_{<63}$ samples, the metal quantities range as follows: As $2.92-9.51 \mathrm{mg} / \mathrm{kg}, \mathrm{Cd} 0.19-3.55 \mathrm{mg} /$ $\mathrm{kg}$, Co 5.12-20.85, Cr 39.46-119.84, Cu 45.97-188.89 and $\mathrm{Ni} 31.18-85.22 \mathrm{mg} / \mathrm{kg}$ (Table 2). The highest values were determined in the case of $\mathrm{Pb}$ and $\mathrm{Zn}, 39-342$ and $126-1198 \mathrm{mg} / \mathrm{kg}$, respectively.

The results were compared with the upper limits in force in the Polish legal regulations referring to the Polish land classification (Minister 2002, Ministerie 2000; Alexander 2006). If the areas of seven spas investigated here were included into the group A (i.e., protected areas), the contents of three elements in all the samples $(100 \%)$ exceed the permissible limits (Minister 2002): $\mathrm{Cu}-$ of $30 \mathrm{mg} / \mathrm{kg}$, $\mathrm{Pb}-$ of $50 \mathrm{mg} / \mathrm{kg}$ and $\mathrm{Zn}-$ of $100 \mathrm{mg} / \mathrm{kg}$. In $86 \%$ and $91 \%$ of the samples the results exceed the upper legal limits of $\mathrm{Cr}-50 \mathrm{mg} / \mathrm{kg}$ and $\mathrm{Ni}-35 \mathrm{mg} / \mathrm{kg}$, respectively. In the case of $\mathrm{Cd}, 18 \%$ of the samples exceed the upper limit of $1 \mathrm{mg} /$ $\mathrm{kg}$, and in the case of Co only $9 \%$ of the samples exceeds the limit of $20 \mathrm{mg} / \mathrm{kg}$. In the case of As, none of the samples exceeds the limit of $20 \mathrm{mg} / \mathrm{kg}$. If the spa areas belonged to the group B (i.e., areas other than the protected and industrial ones), more samples would have higher limits. In the case of $\mathrm{As}, \mathrm{Cd}, \mathrm{Cr}$ and $\mathrm{Ni}$, the upper element contents 20, 4, 150 and $100 \mathrm{mg} / \mathrm{kg}$ (Minister 2002), respectively, are not exceeded in all the samples (100\%). In the case of $\mathrm{Co}$ and $\mathrm{Cu}$ only $9 \%$ of the samples do not meet legal requirements of 20 and $150 \mathrm{mg} / \mathrm{kg}$, 

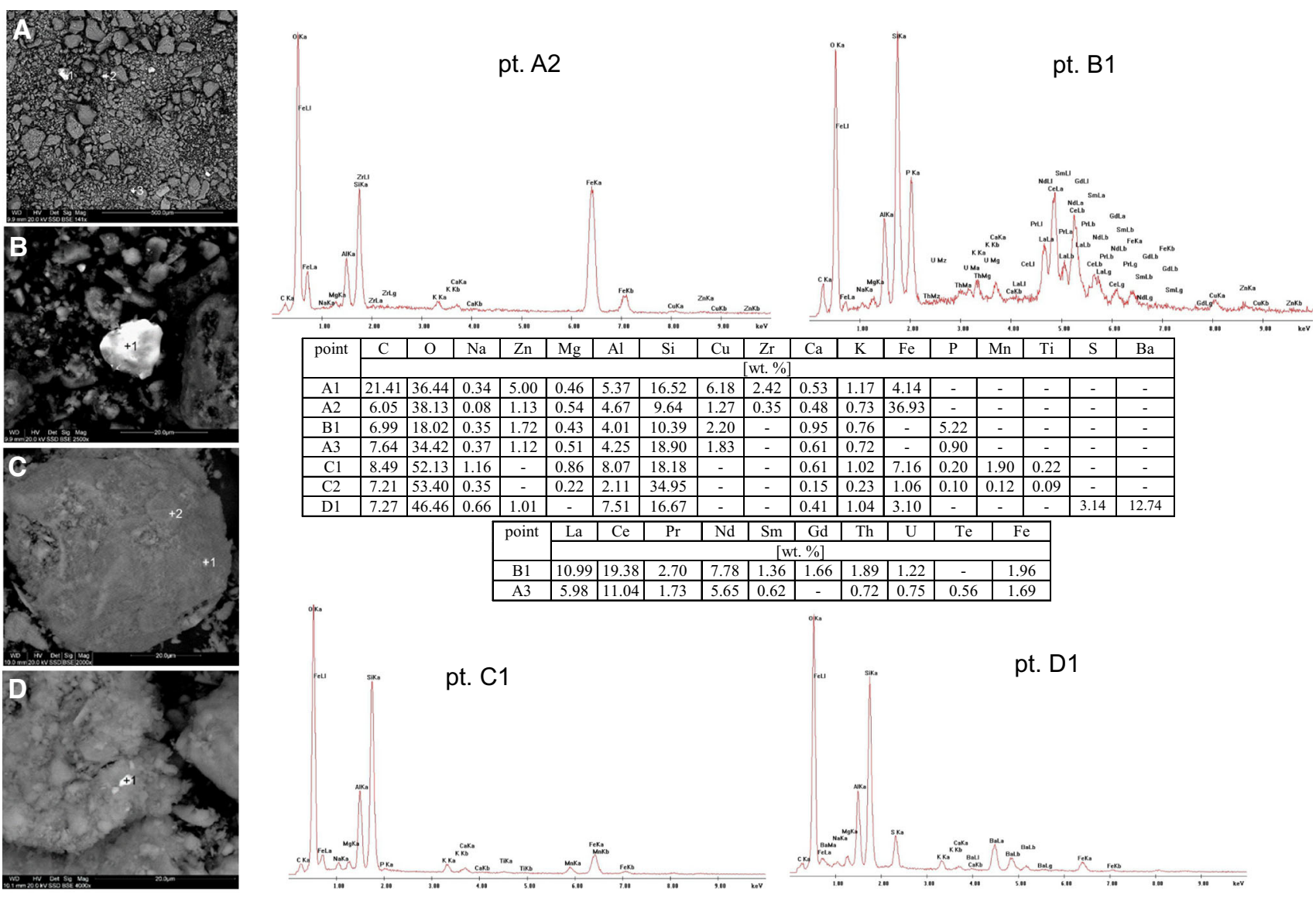

Fig. 5 SEM images and EDS spectra of sand samples F $<63 \mu \mathrm{m}$ collected in Swoszowice (a, b) and in Szczawnica (c, d) "-" not identified

respectively, whereas in the case of Zn $23 \%$ of the samples exceed a limit of $300 \mathrm{mg} / \mathrm{kg}$. The highest number of samples, $46 \%$, exceed the upper limit of $\mathrm{Pb}-100 \mathrm{mg} / \mathrm{kg}$.

In the Dutch regulations (Ministerie 2000), the standards for $\mathrm{Cd}$ and $\mathrm{Co}$ are much more restrictive and for $\mathrm{Cr}, \mathrm{Pb}$ and $\mathrm{Zn}$ slightly less restrictive than in Poland, while for $\mathrm{As}, \mathrm{Cu}$ and $\mathrm{Ni}$ are almost the same, if considering the areas belonging to the Polish group A. Comparing the spa contents of the finest fraction (Table 2) none of the samples exceeds the Dutch limit of As, $14 \%$ exceeds this limit of $\mathrm{Cr}, 32 \%$ of $\mathrm{Cd}, 64 \%$ of $\mathrm{Pb}, 86 \%$ of $\mathrm{Ni}, 91 \%$ of $\mathrm{Co}, 95 \%$ of $\mathrm{Zn}$ and $100 \%$ of $\mathrm{Cu}$.

Assessing the spa samples according to the Norwegian standards (Alexander 2006), none of the samples exceeds their upper limits of $\mathrm{As}, \mathrm{Cd}$ and $\mathrm{Ni}$, while all the samples contain more $\mathrm{Cr}$ than the upper limit of $5 \mathrm{mg} / \mathrm{kg}$. In the case of $\mathrm{Pb}$, almost half of the samples (46\%) contains more leas than its limit of $100 \mathrm{mg} / \mathrm{kg}$. For the three remaining elements, i.e., $\mathrm{Co}, \mathrm{Cu}$ and $\mathrm{Zn}$, there are no standards in Norway.

Analysing the distribution of the elements within the spas, the highest quantities of $\mathrm{Cd}, \mathrm{Cr}, \mathrm{Cu}, \mathrm{Ni}, \mathrm{Pb}$ and $\mathrm{Zn}$ are in Swoszowice, located adjacent to the Cracow agglomeration of almost 1 million inhabitants (Fig. 1). The lowest quantities of $\mathrm{Cd}, \mathrm{Cu}, \mathrm{Pb}$ and $\mathrm{Zn}$ occur in samples from Muszyna, a spa without any industry, while the lowest quantities of As, Co and Ni in Rabka. The samples lowest in $\mathrm{Cu}$ were collected in Krynica, but on the other hand this spa has the highest sample content of As.

Correlation coefficients $\left(r^{2}\right.$, for $\left.p=0.05\right)$ of the metals contained in the finest fraction $\mathrm{F}_{<63}$ are highly correlated $\left(0.5 \leq \mathrm{r}^{2}<0.7\right)$ in the case of three pairs: $\mathrm{Co} / \mathrm{Cr}, \mathrm{Cu} / \mathrm{Ni}$ and $\mathrm{Pb} / \mathrm{Zn}$ (Table 3). A very strong correlation $\left(0.7 \leq \mathrm{r}^{2}<0.9\right)$ show $\mathrm{Cr} / \mathrm{Cu}, \mathrm{Co} / \mathrm{Ni}$ and $\mathrm{Cd} / \mathrm{Zn}$, while almost fully correlated $\left(0.9 \leq \mathrm{r}^{2}<1\right)$ is the pair $\mathrm{Cr} / \mathrm{Ni}$. Very close to these figures are the data of Ajmone-Marsan et al. (2008) for 500 soil samples from five European towns. The Pearson correlation coefficients for $\mathrm{Ni} / \mathrm{Cr}$ concentrations was 0.92 , and for $\mathrm{Zn} / \mathrm{Pb}$ the $\mathrm{r}^{2}$ value was 0.66. The calculations of the Polish spa values and the comparison of the results above indicate that the road traffic contaminations resulting from the fuel combustion and common wearing away of vehicle parts are main 


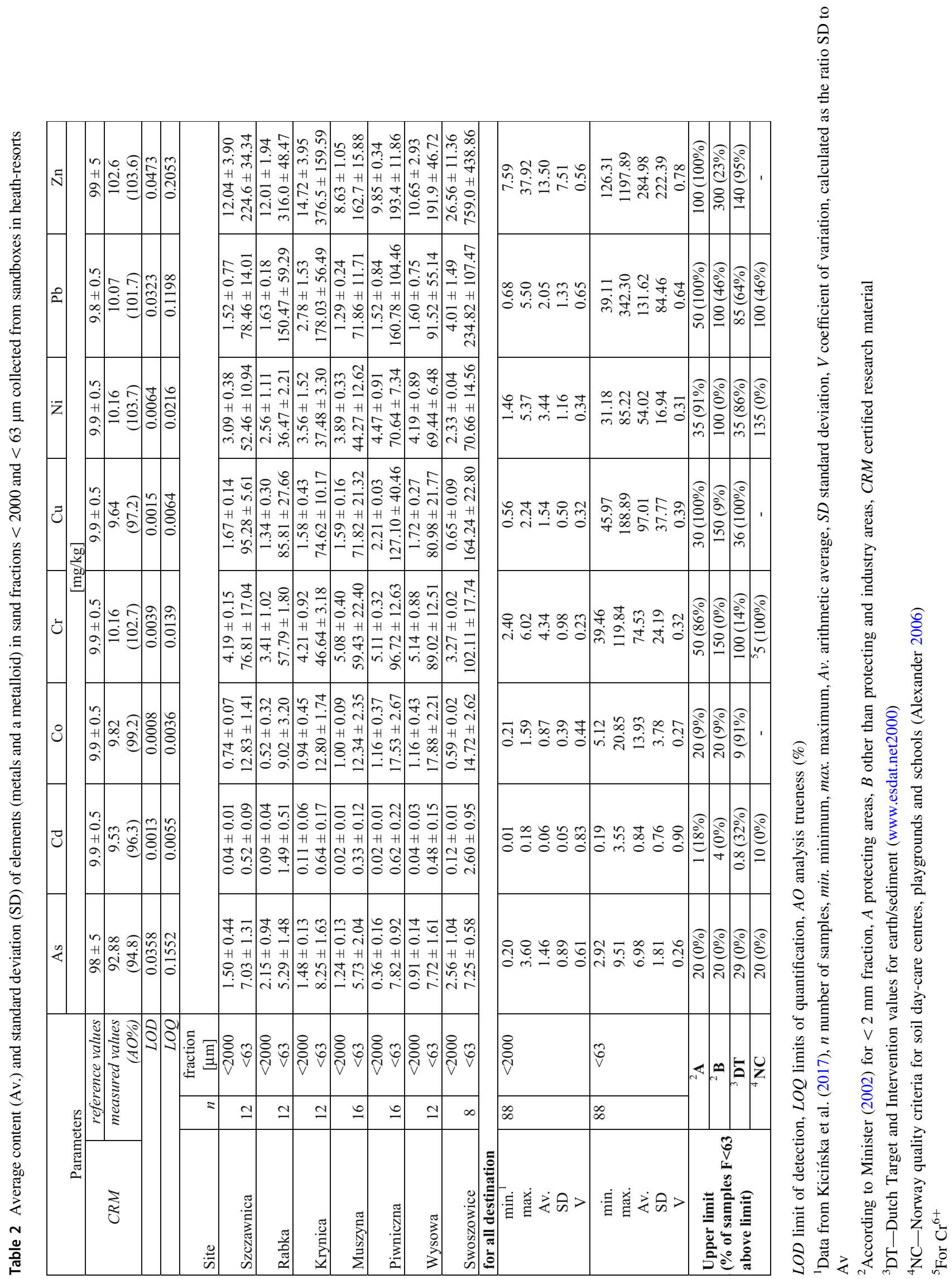


Table 3 Correlation coefficients $\left(r_{x y}\right)$ calculated for the total content of metals in sand faction $<63 \mu \mathrm{m}$

\begin{tabular}{|c|c|c|c|c|c|c|c|}
\hline Element & $\mathrm{Cd}$ & Co & $\mathrm{Cr}$ & $\mathrm{Cu}$ & $\mathrm{Ni}$ & $\mathrm{Pb}$ & $\mathrm{Zn}$ \\
\hline As & -0.06 & 0.29 & $0.44 *$ & 0.37 & $0.45^{*}$ & $0.46^{*}$ & 0.19 \\
\hline $\mathrm{Cd}$ & - & -0.03 & 0.28 & $0.46^{*}$ & 0.21 & $0.47 *$ & $0.85^{* * *}$ \\
\hline Co & & - & $0.61^{* *}$ & 0.33 & $0.80 * * *$ & 0.14 & 0.03 \\
\hline $\mathrm{Cr}$ & & & - & $0.75 * * *$ & $\underline{\mathbf{0 . 9 5}} * * *$ & 0.34 & 0.24 \\
\hline $\mathrm{Cu}$ & & & & - & $\mathbf{0 . 6 6} * * *$ & $0.74 * * *$ & $0.49 *$ \\
\hline $\mathrm{Ni}$ & & & & & - & 0.28 & 0.21 \\
\hline $\mathrm{Pb}$ & & & & & & - & $0.64 * *$ \\
\hline $\mathrm{Zn}$ & & & & & & & - \\
\hline
\end{tabular}

Bold: high correlation $(0.5 \leq \mathrm{r}<0.7)$; Bold italic: very high correlation $(0.7 \leq \mathrm{r}<0.9)$; Bold with underline: almost full correlation $(0.9 \leq \mathrm{r}<1)$

Statistically significant at: $* p<0.05 ; * * p<0.01 ; * * * p<0.001$ sources of the metals mentioned that form the correlated pairs.

The quantities of metals, As including, in the fractions $\mathrm{F}_{<63}$ are very close to the data of De Miguel et al. (2007) for the parks in Madrid but only in the case of As, whose soil and airborne dust contents of the urban parks ranged $3.7-16 \mathrm{mg} / \mathrm{kg}(6.9 \mathrm{mg} / \mathrm{kg}$ on the average $)$ in 2003 . In the case of $\mathrm{Cd}, \mathrm{Cu}, \mathrm{Pb}$ and $\mathrm{Zn}$, the spa sample contents are 3-4 times lower than the figures for Madrid (op. cit.). A reason of such a difference may be caused by various fractions of the material studied: the Spanish data were obtained for the grain fractions $<100 \mu \mathrm{m}$.

\subsection{Distribution of metals throughout the grain fractions}

The comparisons of the metal quantities in the bulk samples $\left(F_{<2000}\right)$ to those in the finest grain fractions $F_{<63}$ reveal significant differences (Fig. 6). The mean element contents of the bulk material for all the samples are: As 1.46, Cd 0.06, Co 0.87, Cr 4.34, Cu 1.54, Ni 3.44, Pb 2.05 and $\mathrm{Zn} 13.50 \mathrm{mg} / \mathrm{kg}$, whereas the respective values for the finest fractions are: As 6.98, Cd 0.84, Co 13.93, Cr 74.53, $\mathrm{Cu}$ 97.01, Ni 54.02, Pb 131.62 and $\mathrm{Zn} 284.98 \mathrm{mg} / \mathrm{kg}$. The Student's $t$ test (assuming $p=0.05$ ) applied for both sets reveals significant differences of the quasi-total contents of all the elements between $\mathrm{F}_{<2000}$ and $\mathrm{F}_{<63}$ (Fig. 7).

The samples of finest material contain significantly higher quantities of metals than the bulk samples. The most differ the values of $\mathrm{Cu}$ and $\mathrm{Pb}$ whose quantities are 63 times higher. The ranking list is followed by $\mathrm{Zn}$ with the 21-time difference; $\mathrm{Cr}, \mathrm{Ni}$ and $\mathrm{Co}$ - the differences are around 16 times; $\mathrm{Cd} 13$ times, while As-the lowest one barely reaching 5 times. Guney et al. (2010) also report significant differences in the quantity of elements in the material collected in the parks of Istanbul. The samples richest in the clay fraction (they contribute $22-26 \%$ to the bulk samples with grains $<2 \mathrm{~mm}$ ) revealed the highest $\mathrm{Cr}$ contents (up to $186 \mathrm{mg} / \mathrm{kg}$ ), $\mathrm{Cu}$ (up to $230 \mathrm{mg} / \mathrm{kg}$ ) and $\mathrm{Zn}$ (up to $182 \mathrm{mg} / \mathrm{kg}$ ), while the averages of the bulk samples $45.8,59.8$ and $53.0 \mathrm{mg} / \mathrm{kg}$, respectively.

In the case of the remaining grain fractions from the Polish spas $\left(F_{2000-1000}, F_{1000-200}, F_{200-63}\right)$, their differences related to the bulk samples were higher but weaker expressed than those in the finest fraction $F_{<63}$. The quantities of the elements have been recalculated into their contributions (Table 4) and ranked in the decreasing order:

- for As and $\mathrm{Cd}: \mathrm{F}_{<63}>>\mathrm{F}_{2000-1000}>\mathrm{F}_{1000-200}$ $>\mathrm{F}_{200-63}$,

- for $\mathrm{Co}, \mathrm{Cu}$ and $\mathrm{Ni}: \mathrm{F}_{<63}>>\mathrm{F}_{2000-1000}$ $\cong \mathrm{F}_{200-63}>\mathrm{F}_{1000-200}$,

- for $\mathrm{Cr}, \mathrm{Pb}$ and $\mathrm{Zn}: \mathrm{F}_{<63}>>\mathrm{F}_{200-63}$ $\cong \mathrm{F}_{2000-1000}>\mathrm{F}_{1000-200}$.

In the fraction $\mathrm{F}_{<63}$, considerably higher metal contributions range from $57.3 \%$ for As to even $96.4 \%$ for $\mathrm{Pb}$. Considering only these two elements (As and $\mathrm{Pb}$ ), the remaining ranges are: from $1.5 \% \mathrm{~Pb}$ to $8.9 \% \mathrm{As}$ in the fraction $\mathrm{F}_{200-63}$, from $0.9 \% \mathrm{~Pb}$ to $12.5 \%$ As in the fraction $\mathrm{F}_{1000-200}$, and from $1.3 \% \mathrm{~Pb}$ to $21.3 \% \mathrm{As}$ in the fraction $\mathrm{F}_{2000-1000}$.

The diagram of the metal contributions in the most polluted samples (Piwniczna P2, Wysowa W3, Fig. 8a, b) and of the mean metal contributions in all the grain fractions of all the samples (Fig. 8c) univocally indicates that most of the elements are accumulated in the finest fraction $\left(\mathrm{F}_{<63}\right)$ : they concentrate $89 \% \mathrm{As}, 93-95 \% \mathrm{Cd}, \mathrm{Co}, \mathrm{Cr}, \mathrm{Ni}$ and $\mathrm{Zn}$, and $98.4 \% \mathrm{Cu}$ and $\mathrm{Pb}$ contained in the bulk samples $(<2 \mathrm{~mm})$.

This tendency is even better expressed after calculating the distribution factor $(D F)$ as the quotient "fraction content to bulk content" (Eq. 6). The highest are the $D F$ values of the fraction $\mathrm{F}_{<63}$ and equal to (in the decreasing rank of elements): $\mathrm{Pb}$ 11.71, $\mathrm{Cu}$ 11.19, Cr 8.41, Co 8.08, Ni 8.06, Zn 7.18, Cd 4.64 and As 4.09 (Table 5). The metal enrichment of the finest fractions is significant, above four 

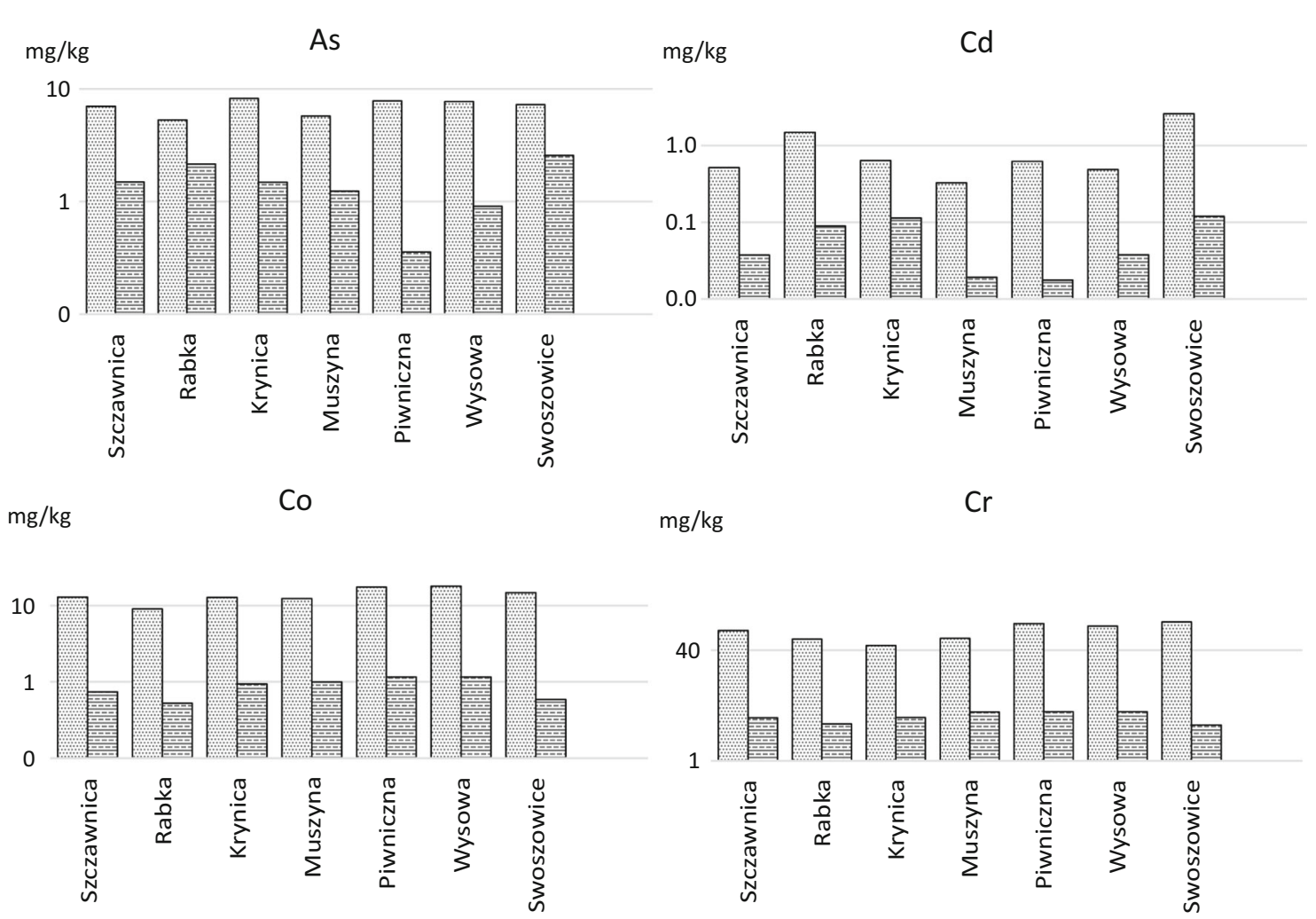

$\mathrm{mg} / \mathrm{kg}$

$\mathrm{Cu}$

$\mathrm{mg} / \mathrm{kg}$

$\mathrm{Ni}$

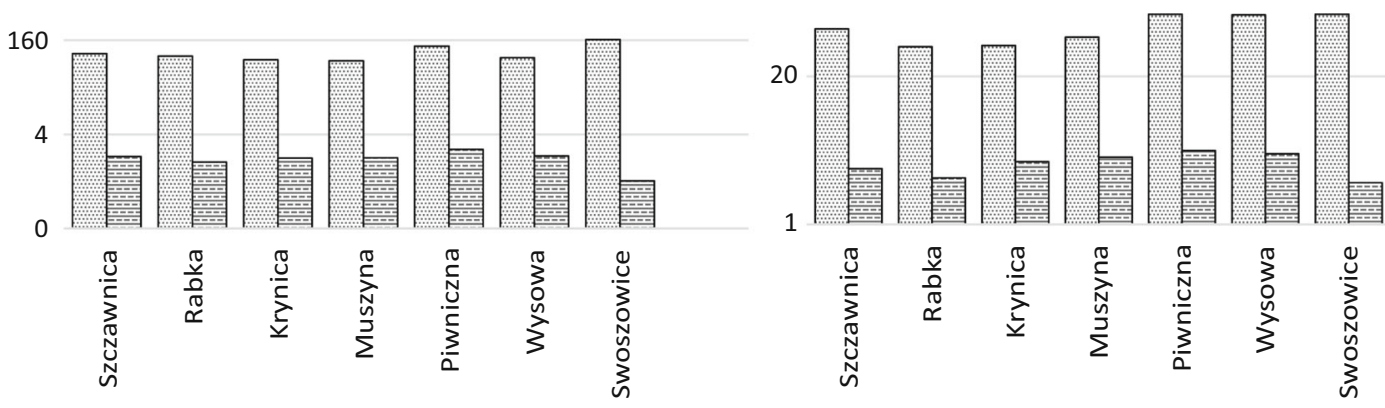

$\mathrm{mg} / \mathrm{kg}$

$\mathrm{Pb}$

$\mathrm{mg} / \mathrm{kg}$

$\mathrm{Zn}$

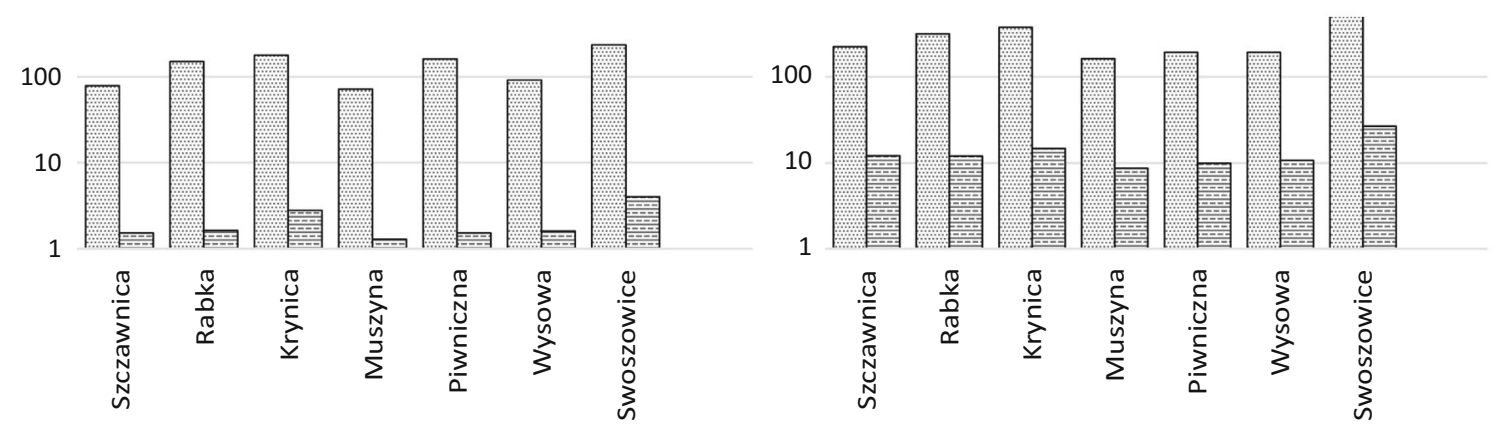

fraction: $\square<63 \mu \mathrm{m}$ 国 $<2000 \mu \mathrm{m}$

Fig. 6 Concentration of elements in sand samples: fractions $\mathrm{F}<2000$ and $\mathrm{F}<63 \mu \mathrm{m}$ 
Fig. 7 Scatters of elements content in sand samples in fractions $\mathrm{F}<2000$ and $\mathrm{F}<63 \mu \mathrm{m} A v$ average, $S D$ standard deviation
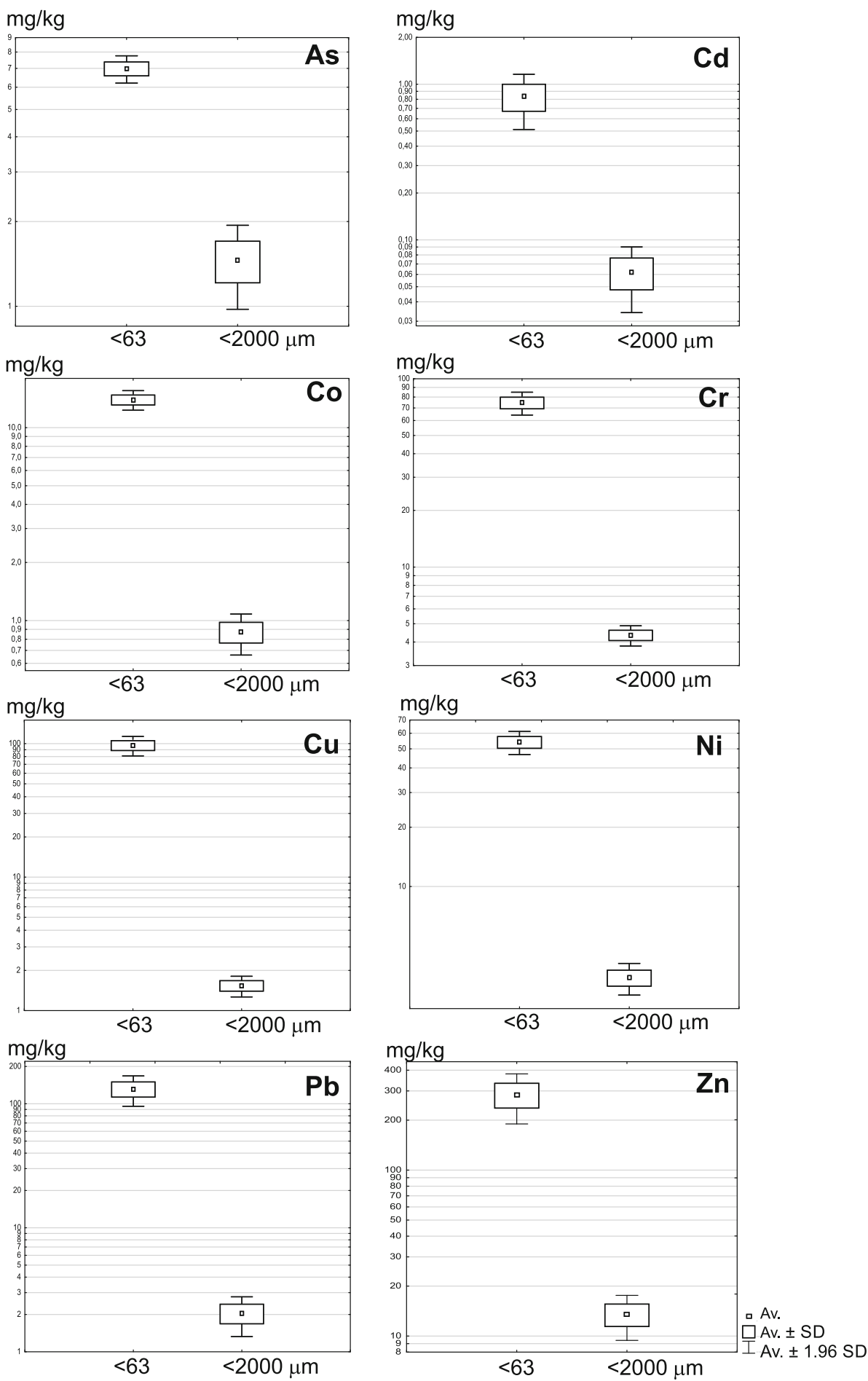

times, and the accumulation sequence of the $\mathrm{F}_{<63}$ is as follows:

$\mathrm{Pb}=\mathrm{Cu}>\mathrm{Cr} \cong \mathrm{Co}=\mathrm{Ni} \cong \mathrm{Zn}>>\mathrm{Cd}=\mathrm{As}$

Considering the remaining fractions and elements, it is only a single fraction $\mathrm{F}_{2000-1000}$ with the $D F$ index 1.52 for As that is a single enriched element.

\subsection{Health risk for children}

In the calculations of the health risk indexes, the finest fractions $\mathrm{F}_{<63}$ that concentrate the highest quantities of elements and represent the most serious health threat. The time that children spent in the spa resorts playing in the open $(E F)$ is also an important factor to be considered. Two 
Table 4 Contributions of elements to separated sand fraction for all spa-resort

\begin{tabular}{llllllllll}
\hline Fraction $(\mu \mathrm{m})$ & Parameter & $\begin{array}{l}\mathrm{As} \\
(\%)\end{array}$ & $\mathrm{Cd}$ & $\mathrm{Co}$ & $\mathrm{Cr}$ & $\mathrm{Cu}$ & $\mathrm{Ni}$ & $\mathrm{Pb}$ & $\mathrm{Zn}$ \\
\hline \multirow{2}{*}{ 2000-1000 } & min.-max. & $4-28$ & $1-15$ & $7-8$ & $4-6$ & $3-7$ & $7-8$ & $1-5$ & $5-9$ \\
& Av. & 21.3 & 10.4 & 7.9 & 4.5 & 3.7 & 7.3 & 1.3 & 6.5 \\
\multirow{2}{*}{$1000-200$} & min.-max. & $7-15$ & $8-14$ & $3-4$ & $3-5$ & $2-4$ & $3-4$ & $1-4$ & $3-5$ \\
& Av. & 12.5 & 10.0 & 3.2 & 3.8 & 2.4 & 3.9 & 0.9 & 3.9 \\
$200-63$ & min.-max. & $8-9$ & $2-6$ & $5-6$ & $7-8$ & $3-5$ & $6-7$ & $1-4$ & $6-8$ \\
& Av. & 8.9 & 4.6 & 5.7 & 6.4 & 3.4 & 6.6 & 1.5 & 6.7 \\
$<63$ & min.-max. & $\mathbf{4 9 - 7 9}$ & $\mathbf{7 0 - 8 4}$ & $\mathbf{8 3 - 8 4}$ & $\mathbf{8 3 - 8 7}$ & $\mathbf{8 3 - 9 3}$ & $\mathbf{8 0 - 8 4}$ & $\mathbf{8 7 - 9 8}$ & $\mathbf{7 9 - 8 6}$ \\
& Av. & $\mathbf{5 7 . 3}$ & $\mathbf{7 5 . 0}$ & $\mathbf{8 3 . 2}$ & $\mathbf{8 5 . 4}$ & $\mathbf{9 0 . 5}$ & $\mathbf{8 2 . 1}$ & $\mathbf{9 6 . 4}$ & $\mathbf{8 2 . 9}$ \\
\hline
\end{tabular}

Bolded share $>50 \%$

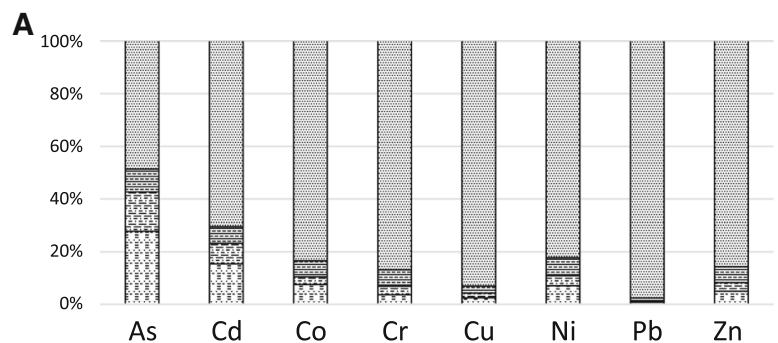

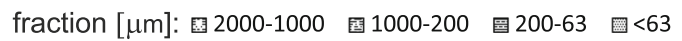

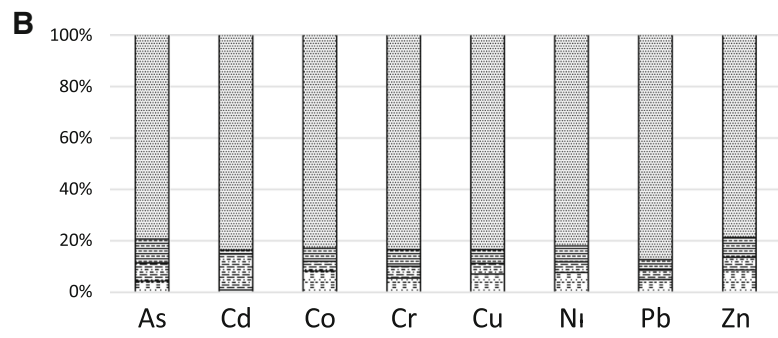

fraction $[\mu \mathrm{m}]$ : 圈2000-1000 圈1000-200 国200-63 圆<63

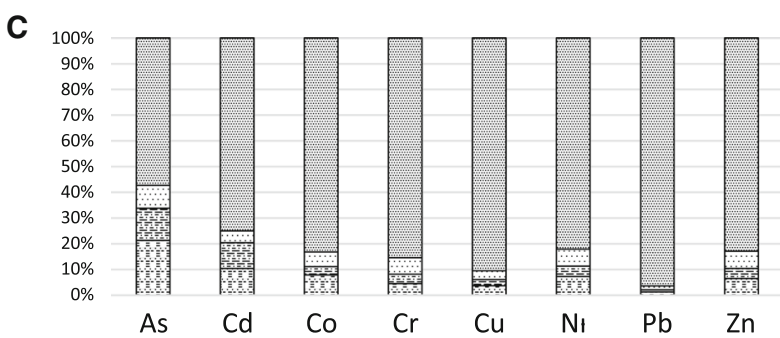

fraction $[\mu \mathrm{m}]:$ 国2000-1000 图 1000-200 回200-63 圆<63

Fig. 8 Content of elements in separated sand fractions. a Piwniczna (P2), b Wysowa (W3) and c all samples $(n=88)$ averaged

groups of children have been distinguished, i.e., residents (permanent stay), for which the $E F=688 \mathrm{~h}$ per year $[365-21$ (holidays) $=344$ days $\times 2 \mathrm{~h}$ spent daily in the open], and visitors, for which the $E F=84 \mathrm{~h}$ per year (21 days $\mathrm{x} 4 \mathrm{~h}$ spent daily in the open). Then, the values of the $\mathrm{D}_{\text {ing }}, \mathrm{D}_{\text {inh }}$ and $\mathrm{D}_{\text {dermal }}$ calculated from the Eqs. (3-5)
Table 5 Distribution factor $(D F)$ of elements in separated sand fractions for all sampling sites

\begin{tabular}{lllllllll}
\hline $\begin{array}{l}\text { Fraction } \\
(\mu \mathrm{m})\end{array}$ & $\mathrm{As}$ & $\mathrm{Cd}$ & $\mathrm{Co}$ & $\mathrm{Cr}$ & $\mathrm{Cu}$ & $\mathrm{Ni}$ & $\mathrm{Pb}$ & $\mathrm{Zn}$ \\
\hline $2000-1000$ & $\mathbf{1 . 5 2}$ & 0.03 & 0.77 & 0.44 & 0.46 & 0.72 & 0.16 & 0.56 \\
$1000-200$ & 0.89 & 0.62 & 0.31 & 0.37 & 0.30 & 0.39 & 0.11 & 0.34 \\
$200-63$ & 0.64 & 0.29 & 0.55 & 0.63 & 0.42 & 0.65 & 0.18 & 0.58 \\
$<63$ & $\mathbf{4 . 0 9}$ & $\mathbf{4 . 6 4}$ & $\mathbf{8 . 0 8}$ & $\mathbf{8 . 4 1}$ & $\mathbf{1 1 . 1 9}$ & $\mathbf{8 . 0 6}$ & $\mathbf{1 1 . 7 1}$ & $\mathbf{7 . 1 8}$
\end{tabular}

Bolded $D F>1$-the metal/metalloid enriched in this fraction

were divided by the respective values of the RfD (US EPA 1986), and the $H Q_{\text {ing }}, H Q_{\text {inh }}$ oraz $H Q_{\text {dermal }}$ established for the children-residents permanently staying in the spa resorts (Table 6) and the children-visitors (Table 7).

For the children 3 and 6 years old being spa residents, the total health indexes $H I$ resulting from the exposure to the non-carcinogenic substances are $1.26 \mathrm{E}+00$ and $9.41 \mathrm{E}-01$, respectively. The $H I$ value exceeds the unity for the 3-hear olds, which means that there is a probability of appearing negative health effects. These children are endangered mainly by three metals: $\mathrm{Pb}\left(H Q_{i}=4.79\right.$ $\mathrm{E}-01), \mathrm{Cr}\left(H Q_{i}=3.43 \mathrm{E}-01\right)$ and $\mathrm{As}\left(H Q_{i}=3.34 \mathrm{E}-01\right)$, whereas the $H Q_{i}$ values of the remaining elements are considerably lower and decrease in the sequence: $\mathrm{Ni}>\mathrm{Cu}>\mathrm{Cd}>\mathrm{Zn}>\mathrm{Co}$. In the case of the 6-year olds, the total indexes of the of health exposure to the noncarcinogenic substances $H I$ are below the unity (9.41E-01), although quite close to it. The differences between the two age groups are caused by the higher body mass of the elder children. The sequence of the endangering elements is the same as before: $\mathrm{Pb}>\mathrm{Cr}>\mathrm{As}>$ $\mathrm{Ni}>\mathrm{Cu}>\mathrm{Cd}>\mathrm{Zn}>\mathrm{Co}$ (Table 6).

The Risk index shows the health impacts of carcinogenic substances. For the 3-year olds it is $6.48 \mathrm{E}-06$, while for the 6-year olds slightly is higher-9.72E-06. The highest negative health contribution for both age groups $(99.51 \%)$ is caused by the As-cancer. In comparison with arsenic, the 


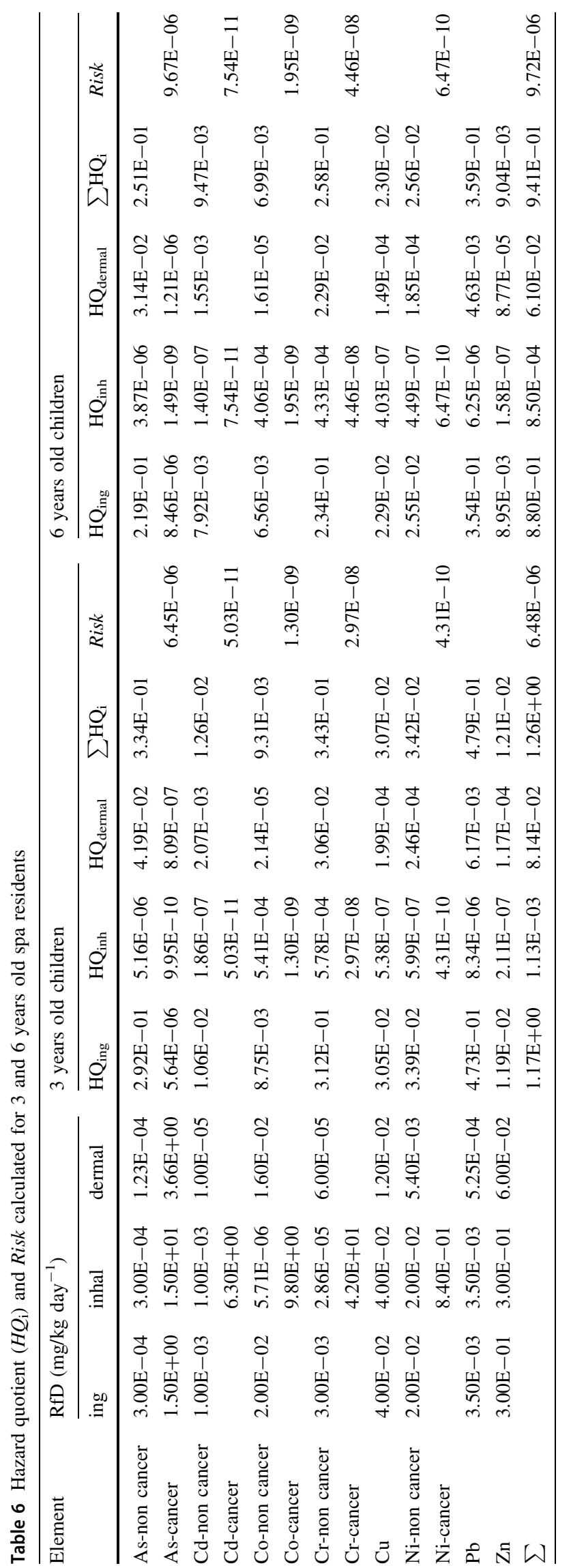




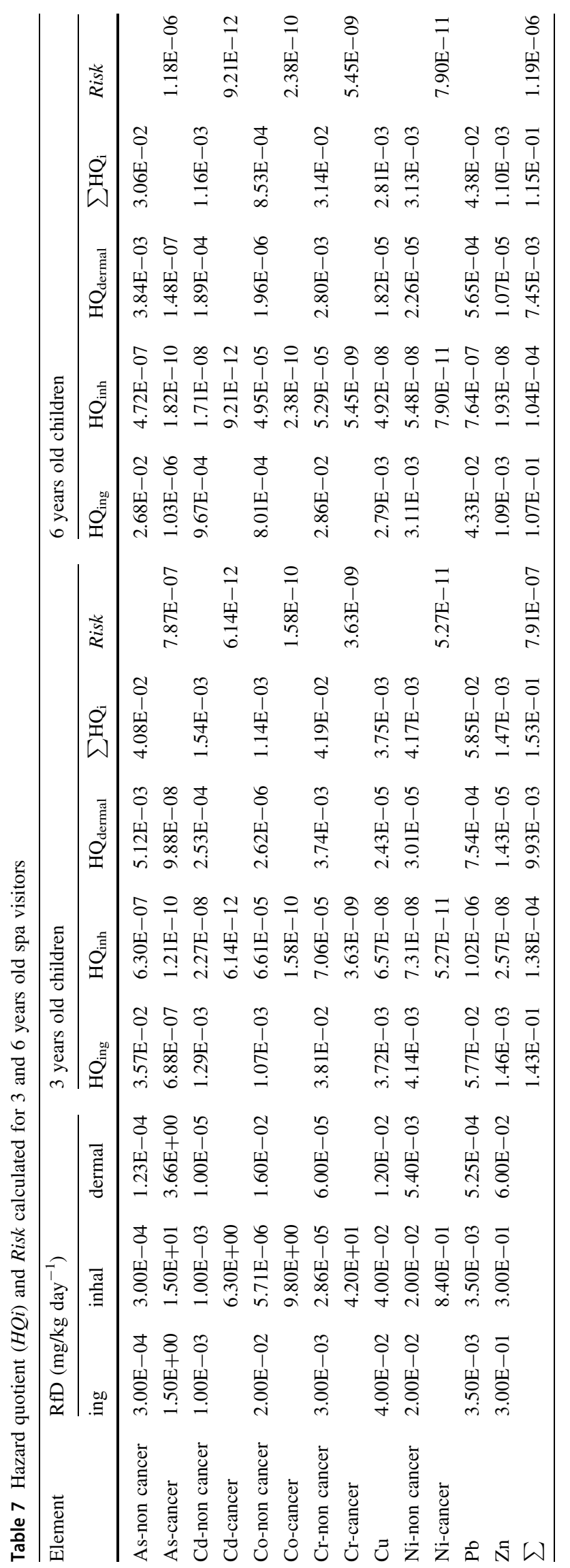



calculated for 3 and 6 years old children for cancer and noncancer elements-sand fraction $\mathrm{F}<63 \mu \mathrm{m}$
Fig. $9 H I$ and Risk values
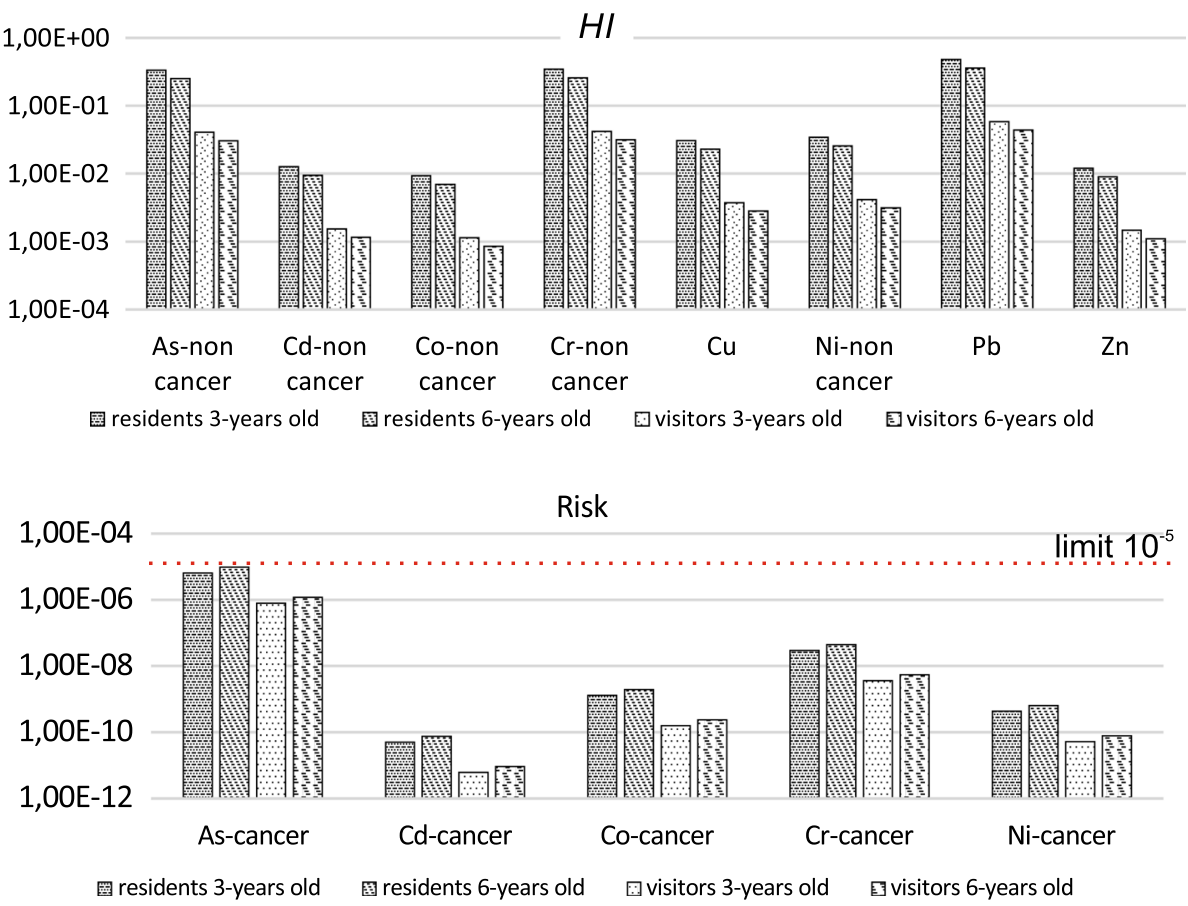

contributions of other three cancer-metals are almost insignificant: $\mathrm{Cr}-0.46 \%, \mathrm{Co}-0.02 \%$ and $\mathrm{Ni}-<0.01 \%$ ). The impact of As caused by swallowing "dirt" (ingestion path) is the highest: above $87 \%$ As enter the organisms in this way; along the dermal paths enters $12.5 \%$, whereas along the inhalation path only $0.01 \%$ As.

For the second group distinguished, i.e., short-term visitors, the total indexes $H I$ of the health exposure to the non-carcinogenic substances are $1.53 \mathrm{E}-01$ and $1.15 \mathrm{E}-01$ for the children 3 and 6 years old, respectively. The $H I$ values below the unity indicate that the health risk resulting from the elements considered in the environment does not exist. The partial $H Q_{i}$ indexes for both age groups are given in Table 7: their values decrease in the order: $\mathrm{Pb}>\mathrm{Cr}>\mathrm{As}>\mathrm{Ni}>\mathrm{Cu}>\mathrm{Cd}>\mathrm{Zn}>\mathrm{Co}$.

The Risk indexes for visitors 3 and 6 years old are 7.91E-07 and 1.19E-06, respectively. These are values lower than those for residents. The upper permissible limit $10 \mathrm{E}-05$ has not been exceeded, which is a satisfactory find of the study (Fig. 9).

For both distinguished groups of children, residents and visitors of the spas, several significant dependencies results been established.

In the case of the carcinogenic substances, they are as follows:

(1) There is no health risk caused by the presence of the carcinogenic forms of $\mathrm{As}, \mathrm{Cd}, \mathrm{Co}, \mathrm{Cr}, \mathrm{Cu}, \mathrm{Ni}, \mathrm{Pb}$ and $\mathrm{Zn}$ for children 3 and 6 years old playing in the spa sandboxes. For both groups the total indexes Risk do not exceed the value $10 \mathrm{E}-05$.
(2) The by far highest contribution to the total Risk results from the As-cancer, which makes up 99.5\% of the Risk value. The As-cancer enters children organisms mostly via the ingestion path (87.4\%), considerably less via the dermal path (12.5\%), and negligibly via the inhalation one (around $0.01 \%$ ).

(3) In the case of the remaining metals, their total indexes Risk are lower than $0.5 \%$, and they enter young organisms mainly via the inhalation path.

In the case of the non-carcinogenic forms, they are as follows

(1) The health risk index $H I$ with the value above the unity $(1.26 \mathrm{E}+00)$ for children 3 and less years old is alarming. The $H I$ is below the limit of $1(9.41 \mathrm{E}-01)$ for the 6-year olds.

(2) The highest health threat in the case of noncarcinogenic substances is caused by $\mathrm{Pb}(38 \%), \mathrm{Cr}$ $(27 \%)$ and $\mathrm{As}(27 \%)$. The partial indexes $H Q_{i}$ calculated for $\mathrm{Ni}, \mathrm{Cu}, \mathrm{Cd}, \mathrm{Zn}$ and $\mathrm{Co}$ are considerably lower than those for $\mathrm{Pb}$ : their total contribution to the total $\mathrm{HI}$ is only $8 \%$ (Fig. 9).

(3) The highest health threat results from the elements entering along the ingestion path $\left(H Q_{\text {ing }}\right)$, which contributes from $87.5 \%$ (for the As-non cancer) to over $99.3 \%$ (for Ni-non cancer) to the total metal indexes $H I$ of the both age groups of children. The other two access paths are of much lower threats: the dermal path contributes from $0.2 \%$ (for the Co-non cancer) to $16.4 \%$ (for the Cd-non cancer). The 
contribution in the case of the inhaling path is low: from $<0.002 \%$ (for $\mathrm{As}, \mathrm{Cd}, \mathrm{Cu}, \mathrm{Ni}, \mathrm{Pb}, \mathrm{Zn}$ ) to almost $6 \%(\mathrm{Co})$

\subsection{Discussion}

The considerations on the values of the indexes $H I$ and Risk focused on the bulk grain fractions and the finest fractions. The former (bulk) contain the material $<2 \mathrm{~mm}$ and give the chemical basis of the study, while the latter contain the material $<63 \mu \mathrm{m}$ which sticks best to the hands of children and its probability to be swallowed is much higher than that of coarser grain fractions (Ljung et al. 2006, Acosta et al. 2009). The finest fractions also become easily airborne and inhaled by children when playing: AjmoneMarsan et al. (2008) identified the fractions $\mathrm{PM}_{2.5}$ and $\mathrm{PM}_{10}$ separated from soils as a potential source of PTE (potentially toxic elements): $\mathrm{Cr}, \mathrm{Ni}, \mathrm{Cu}, \mathrm{Pb}$ and $\mathrm{Zn}$.

Considering the deliberate ingestion of soil (so-called pica behaviour), a daily soil intake is considerably higher and may reach even $10 \mathrm{~g}$ (Ljung et al. 2006). After substituting this value into the equations for $H I$ and Risk, the values of both the indexes are also much higher. For both age groups the values of the $H I$ non-cancer are higher than the unity. For the 3 and 6 years old spa resident these values are $1.10 \mathrm{E}+02$ and $8.26 \mathrm{E}+01$, respectively, while for the spa visitors $1.43 \mathrm{E}+01$ and $1.07 \mathrm{E}+01$, respectively. The Risk values in two age groups (3 and 6-years old) are 5.30E-04 and $7.95 \mathrm{E}-04$ for residents while $6.89 \mathrm{E}-05$ and 1.03E-04 for visitors, and exceed a permissible limit of $10 \mathrm{E}-05$. Therefore, the children with the pica behaviour are at health risk considering the elements considered in the paper.

The indexes $H I$ and Risk calculated on the basis of the quasi-total contents of the metals determined in the bulk samples $\left(\mathrm{F}_{<2000}\right)$ and in the fractions $\mathrm{F}_{<63}$ are presented in Table 8. Their comparison indicate the following.

- The indexes $H I$ and Risk calculated for bulk samples $\left(\mathrm{F}_{<2000}\right)$ are considerably lower than those for the finest fractions $\left(\mathrm{F}_{<63}\right)$.

- In the case of the non-cancer metals, the highest $H I$ values (the figures are quotients expressing $\mathrm{F}_{<63}$ to $\mathrm{F}_{<2000}$ ratios; their pairs refer to children-residents and children-visitors, respectively) are for $\mathrm{Pb}$ (64 and 68, respectively) and $\mathrm{Cu}$ (67 and 63); around 3-3.5 times lower for $\mathrm{Zn}$ (23 and 21), $\mathrm{Cr}$ (18 and 17), Ni and Co (17 and 16), $\mathrm{Cd}$ (15 and 14); whereas for As they are the same (5 and 5). The differences of the indexes $\mathrm{HI}$ in the case of 3- and 6-year olds are insignificant.

- In the case of the cancer-metals, the Risk values (the figures are quotients expressing $\mathrm{F}_{<63}: \mathrm{F}_{<2000}$ ratios; their pairs refer to children-residents and children-visitors, respectively) are exactly the same as those cited above for the non-cancer metals: $\mathrm{Cr}$ (18 and 17, respectively), $\mathrm{Ni}$ and $\mathrm{Co}$ (17 and 16), Cd (15 and 14) and As (5 and 5).

- Higher differences (for $\mathrm{Cu}$ and $\mathrm{Pb}$ equal to 4 , for the remaining metals equal to around 1) occur in the case of children-residents. This is a result of their longer time of staying in the spas (factor $E F$ ) accepted in calculations.

- For children-visitors the differences of the indexes $H I$ and Risk of specific grain fractions are the same as the differences of the quasi-totals of the metals in the fractions (Fig. 9). It is a mathematical result of the equations used.

Comparing the health risk assessments to those presented by other authors is difficult because of the differences in the material used in the determinations (bulk samples, fraction diameters) and various methods of sample decomposition (Table 9). These two methodical steps are major reasons of obtaining differing conclusions. However, there are some similarities of the results presented here to those obtained for the urban parks of Madrid (De Miguel et al. 2007) and Nanjing Wang et al. (2016). They refer mainly to the threats caused by the presence of As, Cr and Zn. Since Wang et al. (op.cit.) also analysed grain fractions $<63 \mu \mathrm{m}$, their results for $\mathrm{As}, \mathrm{Cd}, \mathrm{Cu}, \mathrm{Co}$, $\mathrm{Ni}$ and $\mathrm{Pb}$ very close to ours.

Lower health risk was found in the urban parks of Istanbul (Guney et al. 2010) in the case of As, Cu and Zn. It should be mentioned, however, those authors (Guney et al. 2010) analysed coarser material, i.e., $<2 \mathrm{~mm}$, and in the samples with higher metal quantities also fractions $<0.25 \mathrm{~mm}$. Considering $\mathrm{Cd}, \mathrm{Cr}, \mathrm{Cu}$ and $\mathrm{Zn}$ in the parks of Cracow (Jasiewicz et al. 2009), their threat is more serious than in the spas considered.

\section{Conclusions}

The results obtained in our study on park sandboxes of seven Polish spas indicate that analysing materials of various grain sizes (i.e., various fractions) may lead to highly differing conclusions and assessments children's health. Already the stage of taking samples and preparing them to chemical determinations may involve some simplifications, and the analytical data differ, not saying about the calculated indexes that describe the state of the environment and the human health.

The elements considered: $\mathrm{As}, \mathrm{Cd}, \mathrm{Co}, \mathrm{Cr}, \mathrm{Cu}, \mathrm{Ni}, \mathrm{Pb}$ and $\mathrm{Zn}$ accumulate mainly in the finest of the fractions analysed (i.e., $\mathrm{F}_{<63}$ ). Although the quantity of the finest fractions in the bulk material $<2 \mathrm{~mm}$ is low (for $\mathrm{n}=88$ samples the 
Table 8 Comparison of $H I$ and Risk values calculated for the $\mathrm{F}_{<63}$ and for the $\mathrm{F}_{<2000}$ fractions

\begin{tabular}{|c|c|c|c|c|c|}
\hline \multirow[t]{3}{*}{ Elements } & \multicolumn{2}{|l|}{ HI (non-cancer) } & \multicolumn{2}{|l|}{ Risk (cancer) } & \multirow[t]{3}{*}{ TC (average) $(\mathrm{mg} / \mathrm{kg})$} \\
\hline & Residents & Visitors & Residents & Visitors & \\
\hline & 3 years old & 3 years old & 6 years old & 3 years old & \\
\hline
\end{tabular}

$\frac{F_{<63}}{F_{<2000}}$

$\mathrm{F}_{<2000^{*}}$

As

$\frac{3.34 \mathrm{E}-01}{6.57 \mathrm{E}-02}$

$\frac{2.51 \mathrm{E}-01}{4.92 \mathrm{E}-02}$

$\frac{4.08 \mathrm{E}-02}{8.54 \mathrm{E}-03}$

$\frac{3.06 \mathrm{E}-02}{6.40 \mathrm{E}-03}$

$\frac{6.45 \mathrm{E}-06}{1.27 \mathrm{E}-06}$

$\underline{9.67 \mathrm{E}-06}$

$\frac{7.87 \mathrm{E}-07}{1.65 \mathrm{E}-07}$

$\frac{1.18 \mathrm{E}-06}{2.47 \mathrm{E}-07} \quad \frac{6.98}{1.46}$

Cd

$\frac{1.26 \mathrm{E}-02}{8.47 \mathrm{E}-04} \quad \frac{9.47 \mathrm{E}-03}{6.35 \mathrm{E}-04}$

$\underline{1.54 \mathrm{E}-03}$

$\frac{1.16 \mathrm{E}-03}{8.26 \mathrm{E}-05}$

$\underline{5.03 \mathrm{E}-11}$

$1.90 \mathrm{E}-06$

$1.65 \mathrm{E}-07$

$2.47 \mathrm{E}-07$

Co

$\frac{9.31 \mathrm{E}-03}{5.46 \mathrm{E}-04}$

$\underline{6.99 \mathrm{E}-03}$

$1.10 \mathrm{E}-04$

$\overline{3.37 \mathrm{E}-12}$

$\frac{7.54 \mathrm{E}-11}{5.06 \mathrm{E}-12}$

$\frac{6.14 \mathrm{E}-12}{4.39 \mathrm{E}-13}$

$\frac{9.21 \mathrm{E}-12}{6.58 \mathrm{E}-13} \quad \frac{0.84}{0.06}$

Cr

$\underline{1.14 \mathrm{E}-03}$

$\underline{8.53 \mathrm{E}-04}$

$\frac{1.30 \mathrm{E}-09}{7.61 \mathrm{E}-11}$

$\underline{1.95 \mathrm{E}-09}$

$\underline{1.58 \mathrm{E}-10}$

$\underline{2.38 \mathrm{E}-10} \quad \underline{13.93}$

$\mathrm{Cr}$

$\frac{1.88 \mathrm{E}-02}{3.07 \mathrm{E}-02}$

$\frac{2.58 \mathrm{E}-01}{1.41 \mathrm{E}-02}$

$4.19 \mathrm{E}-02$

$7.61 \mathrm{E}-11 \quad 1.14 \mathrm{E}-10$

$9.89 \mathrm{E}-12$

$1.48 \mathrm{E}-11$

0.87

$\mathrm{Cu}$

$\underline{3.07 \mathrm{E}-02}$

$2.44 \mathrm{E}-03$

$\overline{1.83 \mathrm{E}-03}$

$1.63 \mathrm{E}-09$

$\frac{4.46 \mathrm{E}-08}{2.44 \mathrm{E}-09}$

$\frac{3.63 \mathrm{E}-09}{2.12 \mathrm{E}-10}$

$\frac{5.45 \mathrm{E}-09}{3.17 \mathrm{E}-10}$

$4.57 \mathrm{E}-04 \quad 3.43 \mathrm{E}-04$

$3.75 \mathrm{E}-03$

$5.95 \mathrm{E}-05$

$2.81 \mathrm{E}-03$

$4.46 \mathrm{E}-05$

$\mathrm{Ni}$

$\frac{3.42 \mathrm{E}-02}{2.04 \mathrm{E}-03}$

$2.56 \mathrm{E}-02$

$\underline{4.17 \mathrm{E}-03}$

$\frac{3.13 \mathrm{E}-03}{1.99 \mathrm{E}-04}$

4.31E-10 $\quad 6.47 \mathrm{E}-10$

$2.66 \mathrm{E}-04$

$2.58 \mathrm{E}-11 \quad \frac{6.47 \mathrm{E}-10}{3.87 \mathrm{E}-11}$

$\underline{5.27 \mathrm{E}-11}$

$3.35 \mathrm{E}-12$

$\frac{7.90 \mathrm{E}-11}{5.03 \mathrm{E}-12}$

$\underline{74.53}$

$\mathrm{Pb}$

$\frac{4.79 \mathrm{E}-01}{7.00 \mathrm{E}-03}$

$3.59 \mathrm{E}-01$

$\underline{5.85 \mathrm{E}-02}$

$\frac{4.38 \mathrm{E}-02}{6.83 \mathrm{E}-04}$

(3)

$\begin{array}{ll}\frac{97.01}{1.54} \\ \frac{90 \mathrm{E}-11}{.03 \mathrm{E}-12} & \frac{54.02}{3.44} \\ & \frac{131.62}{2.05} \\ & \frac{284.98}{13.50}\end{array}$

V

$$
\frac{1.21 \mathrm{E}-02}{5.36 \mathrm{E}-04}
$$

$9.04 \mathrm{E}-03$

$9.10 \mathrm{E}-04$

$\frac{1.47 \mathrm{E}-03}{6.97 \mathrm{E}-05} \quad \frac{1.10 \mathrm{E}-03}{5.23 \mathrm{E}-05}$

13.50

$\begin{array}{lll}\mathrm{As} & 5 & 5 \\ \mathrm{Cd} & 15 & 15 \\ \mathrm{Co} & 17 & 17 \\ \mathrm{Cr} & 18 & 18 \\ \mathrm{Cu} & 67 & 67 \\ \mathrm{Ni} & 17 & 17 \\ \mathrm{~Pb} & 68 & 68 \\ \mathrm{Zn} & 23 & 23\end{array}$

$5 \quad 5$

$14 \quad 14$

16

17

63

16

5

14

16

17

63

16

64

64

$5 \quad 5$

$15 \quad 15$

$17 \quad 17$

18

17

5

5

5

5

$14 \quad 14 \quad 14$

$\begin{array}{lll}16 & 16 & 16\end{array}$

16

17

16

17

63

$\begin{array}{llll}17 & 17 & 16 & 16\end{array}$

21

21

* For $\mathrm{F}_{<2000}$ data from Kicińska et al. (2017), $V$ variability coefficient, $H I$ and Risk values calculated by dividing adequate $\mathrm{F}_{<63}$ and $\mathrm{F}_{<2000}$ values

range is $0.32-3.65 \mathrm{wt} \%$ with the average $1.59 \mathrm{wt} \%$ ), the contribution of metals associated with the minerals present in the $\mathrm{F}_{<63}$ ranges from the lowest $57 \%$ of As to the highest $96 \%$ of $\mathrm{Pb}$. The metals are fixed mainly by oxy/hydroxides of $\mathrm{Fe}$ and $\mathrm{Mn}$, and clay minerals (clinochlore, illite, kaolinite).

Despite that the fractions dominating in the sandy samples has the grain size 1000-200 $\mu \mathrm{m}$, their metal contributions to the quasi-total (the totals decomposed in aqua regia) contents ranged from the lowest $1 \% \mathrm{~Pb}$ to the highest $13 \%$ As.

Assessing the state of the environment, none of bulk sandbox samples contains the metals considered above the permitted limits. However, if the finest fractions are considered, their metal contents exceed the limits legally required for soils of the protected areas in $86 \%$ of the sand separates in the case of $\mathrm{Cr}$ and $\mathrm{Ni}$, and in all (100\%) the separates in the case of $\mathrm{Cu}, \mathrm{Pb}$ and $\mathrm{Zn}$.

The grain fractions $<63$ contain significantly more metals than the bulk samples: from the lowest 5 times for As to the highest 64 times for $\mathrm{Pb}$. As a result, these differences directly and decisively affect the calculated values of the indexes $H I$ and Risk for children 3 and 6 years old.

The highest values of the health risk index $H I$ calculated from the quasi-total metal contents in the fractions $\mathrm{F}_{<63}$ have been determined for the children 3 and 6 years old permanently staying in the spas in the case of $\mathrm{Pb}$ (4.79E-01 and 3.59E-01, respectively), $\mathrm{Cr}$ (3.43E-01 and $2.58 \mathrm{E}-01$, respectively) and As (3.34E-01 and $2.51 \mathrm{E}-01$, respectively). In the calculations made for the bulk samples $\mathrm{F}_{<2000}$ the indexes $H I$ are considerably lower for both age groups. For the spa children-residents of both age groups they are, respectively: $7.00 \mathrm{E}-03$ and $5.25 \mathrm{E}-03$ 


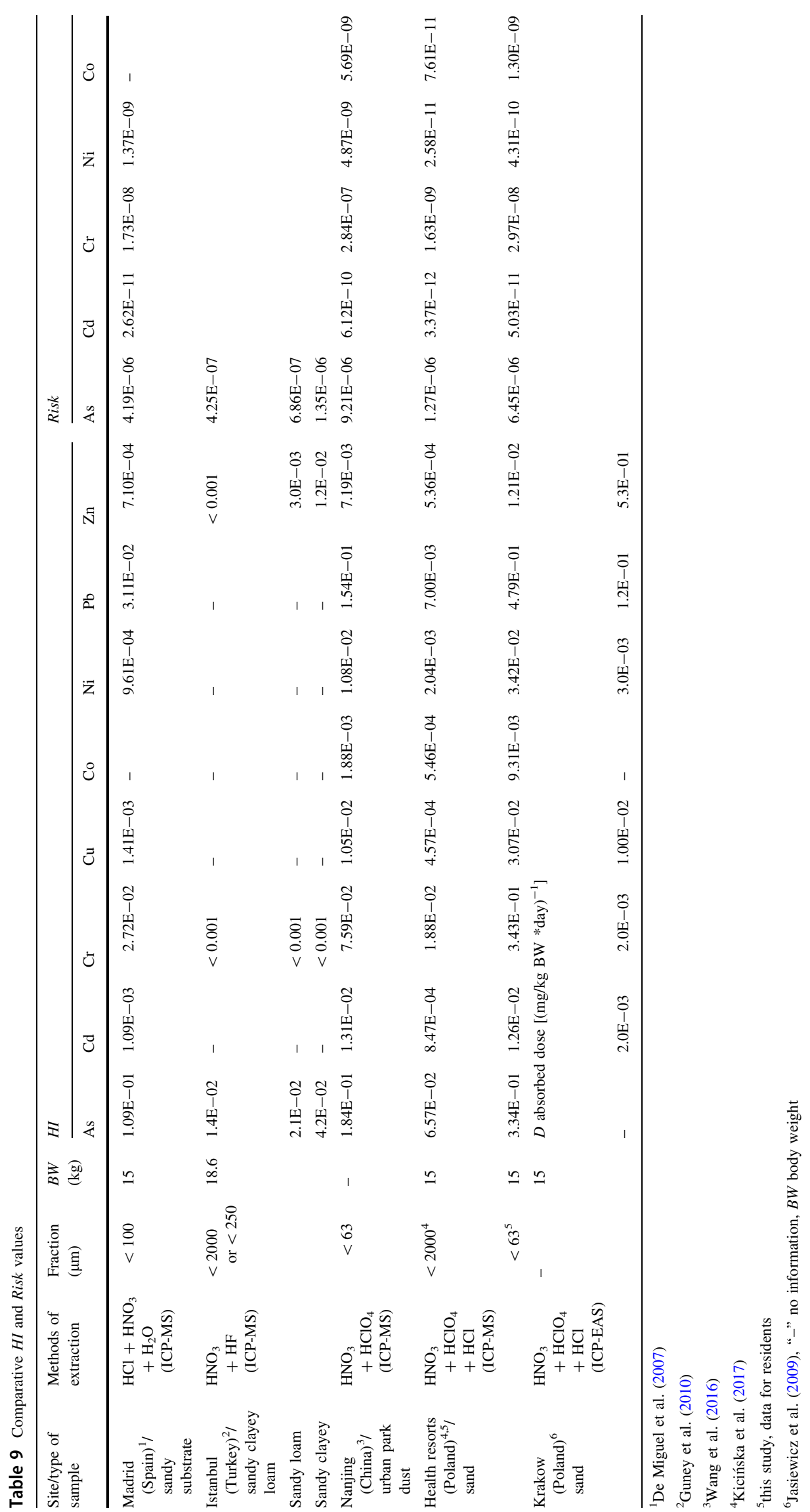


for $\mathrm{Pb}, 1.88 \mathrm{E}-02$ and $1.41 \mathrm{E}-02$ for $\mathrm{Cr}$ and $6.57 \mathrm{E}-02$ and 4.92E-02 for As. The metals considered in the case of non-cancer elements penetrate children's organisms mainly via the digestive path (average $93.4 \%$ for all the elements), occasionally via the dermal path (average 6.5\%), and almost negligibly via the inhaling path (average $0.1 \%$ ).

The highest index Risk caused by carcinogenic substances has been determined in the finest grain fractions $(<63 \mu \mathrm{m})$ for the spa residents: it is 9.67E-06 for the 6 year olds, and $6.45 \mathrm{E}-06$ for the 3 years old. When the Risk calculations were made for the bulk samples, the indexes were significantly lower (1.90E-06 and $1.27 \mathrm{E}-06$, respectively both age groups).

The difference of the indexes $H I$ and Risk for the bulk samples and their finest fractions corresponds to the differences in the metal quantities in both sample types. These differences are also confirmed by the distribution index $D F$. In the case of the finest fraction $\mathrm{F}_{<63}$, its value is the highest and equals 11.71 for $\mathrm{Pb}$, while for the remaining metals the values are significantly lower but exceed $>4$, which proves a high enrichment of the fine fraction in the metals concerned.

The index $H I$ exceeding the unity for the 3-year olds spa residents indicates that negative health effects are probable to appear for children of this age group.

The essential conclusion of the current investigations is that the degree of the human (not only children's) health risk should be assessed carrying out the chemical determinations on the fine fractions $(<63 \mu \mathrm{m})$, in which clay minerals and $\mathrm{Fe}$ and $\mathrm{Mn}$ oxy/hydroxides are accumulated and represent mineral substances with strong sorption/ desorption capacities of such metals as $\mathrm{Pb}, \mathrm{Cu}, \mathrm{Zn}, \mathrm{Cd}$, also $\mathrm{Cr}$ and $\mathrm{Ni}$. These are just the grain fractions sticking most to the hands of children and may be accidentally swallowed when a child concentrates on playing, e.g. in sandboxes. Coarser grain fractions $(>200 \mu \mathrm{m})$ contain insignificant portion of metals if compared with the fractions $<63 \mu \mathrm{m}$, moreover coarser fractions are organoleptically sensed: they usually grit in one's teeth and are at least partly removed with saliva. It is thus the finest fraction$<63 \mu \mathrm{m}$, which should be investigated in the health risk assessments.

Acknowledgements This research was financial support by AGHUST Grant KOŚ No. 11.11.140.017.

Open Access This article is distributed under the terms of the Creative Commons Attribution 4.0 International License (http://crea tivecommons.org/licenses/by/4.0/), which permits unrestricted use, distribution, and reproduction in any medium, provided you give appropriate credit to the original author(s) and the source, provide a link to the Creative Commons license, and indicate if changes were made.

\section{References}

Acosta JA, Cano AF, Arocena JM, Debela F, Martinez SM (2009) Distribution of metals in soil particle size fraction and its implication to risk assessment of playground in Murcia city (Spain). Geoderma 149:101-109. https://doi.org/10.1016/j.geo derma.2008.11.034

Ajmone-Marsan F, Biasioli M, Kralj T, Grcman H, Davidson CM, Hursthouse AS, Madrid L, Rodrigues S (2008) Metals in particle-size fractions of the soils of five European cities. Environ Pollut 152:73-81. https://doi.org/10.1016/j.envpol.2007. 05.020

Ak N, Eroglu E, Guney I (2012) Statistical analysis of soil heavy metals of Istanbul children playgrounds. Energy Educ Sci Technol Part A 28(2):1151-1158

Alexander J (2006) Anbefalte kvalitetskriterier for jord i barnehager, lekeplasser og skolegårder på basert på helsevurderinger (Health-based soil quality criteria for day-care centres playgrounds and schoolyards). Nasjonalt Folkehelseinstitutt, Oslo (in Norwegian)

Al-Hwaiti M, Al-Khashman O (2015) Health risk assessment of heavy metals contamination in tomato and green pepper plants grown in soils amended with phosphogypsum waste materials. Environ Geochem Health 37:287-304. https://doi.org/10.1007/ s10653-014-9646-z

Al-Hwaiti M, Al Kuisi M, Saffarini G, Alzughoul K (2014) Assessment of elemental distribution and heavy metals contamination in phosphate deposits: potential health risk assessment of finer-grained size fraction. Environ Geochem Health 36:651-663. https://doi.org/10.1007/s10653-013-9587-y

Al-Hwaiti M, Brumsack H, Schnetger B (2015) Fraction distribution and risk assessment of heavy metal in waste clay sediment discharged through phosphate beneficiation process in Jordan. Environ Monit Assess 187:401. https://doi.org/10.1007/s10661015-4579-2

Bai J, Ciu B, Wang Q, Gao H, Ding Q (2009) assessment of heavy metal contamination of roadside soils in Southwest China. Stoch Environ Res Risk Assess 23:234-347. https://doi.org/10.1007/ s00477-008-0219-5

Boone RD, Grigal DF, Sollins P, Ahrens RJ, Armstrong DE (1999) Soil sampling, preparation, archiving, and quality control. In: Roertson GP, Coleman DC, Bledsoe CS, Sollins P (eds) Standars soil methods for long-term ecological research. Oxford University Press, New York, pp 3-28

De Miguel E, Iribarren I, Chacon E, Ordonez A, Charlesworth S (2007) Risk-based evaluation of the exposure of children to trace elements in playgrounds in Madrid (Spain). Chemosphere 66:505-513. https://doi.org/10.1016/j.chemosphere.2006.05.065

Diatta JB, Grzebisz W (2011) Simulative evaluation of $\mathrm{Pb}, \mathrm{Cd}, \mathrm{Cu}$, and $\mathrm{Zn}$ transfer to humans: the case of recreational parks in Poznan, Poland. Pol J Environ Study 20(6):1433-1440

Du Y, Gao B, Zhou H, Ju X, Hao H, Yin S (2013) Health risk assessment of heavy metals in road dust in urban parks of Beijng, China. Proced Environ Sci 18:299-309. https://doi.org/10.1016/ j.proenv.2013.04.039

Dziubanek G, Piekut A, Rusin M, Baranowska R, Hajdok I (2015) Contamination of food crops grown on soil with elevated heavy metals content. Ecotoxicol Environ Saf 118:183-189. https://doi. org/10.1016/j.ecoenv.2015.04.032

Figueiredo AMG, Tocchini M, Santos TFS (2011) Metals in playground spoils of Sao Paulo city, Brazil. Proced Environ Sci 4:303-309. https://doi.org/10.1016/j.proenv.2011.03.035 
Gong C, Ma L, Cheng H, Liu Y, Xu D, Li B, Liu F, Ren Y, Liu Z, Zhao C, Yang K, Nie H, Lang C (2014) Characterization of the particle size fraction associated heavy metals in tropical arable soils from Hainan Island, China. J Geochem Explor 139:109-114

Guney M, Zgury GJ, Dogan N, Onay T (2010) Exposure assessment and risk characterization from trace elements following soil ingestion by children exposed to playgrounds, parks and picnic areas. J Hazard Mater 182:656-664. https://doi.org/10.1016/j. hazmat.2010.06.082

Hlavay J, Polyak K, Wesemann G (1992) Particle size distribution of mineral phases and metals in dust collected at different workplaces. Fresenius J Anal Chem 344:319-321

Islam MS, Ahmed MK, Mamun MH (2016) Apportionment of heavy metals in soil and vegetables and associated health risk assessment. Stoch Environ Res Risk Assess 30:365-377. https://doi.org/10.1007/s00477-015-1126-1

Jartun M, Ottesen RT, Steinnes E (2003) Urban soil pollution and the playfields of small children. J Phys IV Fr 107:671-674. https:// doi.org/10.1051/jp4:20030392

Jasiewicz C, Baran A, Antonkiewicz J (2009) Assessment of chemical composition and sanitary state of sand in selected sandboxes in Krakow. J Elementol 14(1):79-90

Kabata-Pendias A, Pendias H (1999) Biogeochemistry of trace elements. PWN, Warsaw, pp 279-288

Kicińska A (2016a) Health risk to children exposed to $\mathrm{Zn}, \mathrm{Pb}$ and $\mathrm{Fe}$ in selected urban parks of the Silesian agglomeration. Hum Ecol Risk Assess Int J 22(8):1687-1695. https://doi.org/10.1080/ 10807039.2016.1218271

Kicińska A (2016b) Risk assessment of children's exposure to potentially harmful elements (PHE) in selected urban parks of the Silesian agglomeration. In: E3S web of conferences 10, 00035. https://doi.org/10.1051/e3sconf/20161000035

Kicińska A, Mamak M, Skrzypek M (2017) Heavy metals in sandboxes: health risk associated with their quantities and form of occurrence in some spas of Poland. Environ Sci Pollut Res 24:19733-19748. https://doi.org/10.1007/s11356-017-9531-2

Klojzy-Karczmarczyk B (2014) Variability of mercury content in various fractions of soils from the vicinity of Krakow ring road section. Rocznik Ochrona Środowiska 16:363-375

Kosa B, Kicińska A (2016) Coal from the waste disposal site of the Siersza mine (Trzebinia, Poland) and its properties as a possible alternative fuel. In: E3S web of conferences 10, 00039. https:// doi.org/10.1051/e3sconf/20161000039

Ljung K, Selinus O, Otabbong E, Berglund E (2006) Metal and arsenic distribution in soil particle sizes relevant to soil ingestion by children. Appl Geochem 21:1613-1624. https://doi.org/10. 1016/j.apgeochem.2006.05.005

Marjanović MD, Vukčević MMm, Antonović DG, Dimitrijević SI, Jovanović DM, Matavulj MN, Ristić MD (2009) Heavy metals concentration in soils from parks and green areas in Belgrade. J Serb Chem Soc 74(6):697-706. https://doi.org/10.2298/ JSC0906697M

Migaszewski Z, Gałuszka A (2016) Environmental geochemistry. PWN, Warsaw

Minister of the Environment of 1 September 2016, Regulation of the method of conducting the assessment of surface pollution, Dz U.poz. 1395

Minister of the Environment of 9 September 2002, Regulation of soil quality standards and earth quality standards, Dz.U.165, 1359
Ministerie van Volkshuisvesting (2000) Ruimtelijke Ordening en Milieubeheer, Dutch Target and Intervention Values 2000. www. esdat.net/EnvironmentalStandard/Dutch/annexS.12000

Ministry of the Environment, Japan (2003). www.env.go.jp/water/ dojo/law/kokuji/o4.pdf

Niec J, Baranowska R, Dziubanek G, Rogala D (2013) Children's exposure to heavy metals in the soils of playgrounds, sports fields, sandpits and kindergarten grounds in the region of Upper Silesia. J Ecol Health 17(2):55-62

Sotch L (1974) Clay minerals, Wyd Geol (In Polish)

Stajic JM, Milenkovic B, Pucarevic M, Stojic N, Vasiljevic I, Nikezic D (2016) Exposure of school children to polycyclic aromatic hydrocarbons, heavy metals and radionuclides in the urban soil of Kragujevac city, Central Serbia. Chemosphere 146:6874. https://doi.org/10.1016/j.chemosphere.2015.12.0060045-6535

Stala-Szlugaj K (2016) Trends in the consumption of hard coal in Polish households compared to EU households. Min Resour Manag 32(3):5-22. https://doi.org/10.1515/gospo-2016-0024

Taiwo AM, Awomeso JA, Taiwo OT, Oremodu BD, Akintunde OO, Ojo NO, Elegbede OO, Olanrewaju HH, Arowolo TA (2017) Assessment of health risk associated with road dust in major traffic hotspots in Abeokuta metropolis, Ogun state, southwestern Nigeria. Stoch Environ Res Risk Assess 31:431-447. https:// doi.org/10.1007/s00477-016-1302-y

US EPA (1986) Guidelines for human health risk assessment of chemical mixtures. Federal Register (51 FR 34014-34025), Washington

US EPA (1996) Method 3050B: acid digestion of sediments, Sludges, and Soils, Revision 2

US EPA (1997) Exposure factors handbook-general factors. EPA/ 600/P-95/002Fa, vol. I. Office of Research and Development. National Center for Environmental Assessment. US Environmental Protection Agency. Washington. www.epa.gov/ncea/ pdfs/efh/front.pdf

US EPA (2005) Integrated Risk Information System (IRIS). www. epa.gov/iris

US EPA (2011) Exposure factors handbook: 2011 Edition (EPA/600/ R-09/052F), https://cfpub.epa.gov/ncea/risk/recordisplay.cfm?de $\mathrm{id}=236252$

Valskys V, Ignatavicius G, Sinkevicius S, Gasiunaite U (2016) Soil contamination by heavy metals in playgrounds of kindergartens in Vilnius. J Environ Sci Int 25(1):11-21. https://doi.org/10. 5322/JESI.2016.25.1.11

Wang J, Li S, Cui X, Li H, Qian X, Wang C, Sun Y (2016) Bioaccessibility, sources and health risk assessment of trace metals in urban park dust in Nanjing, southeast China. Ecotoxicol Environ Saf 128:161-170. https://doi.org/10.1016/j.ecoenv. 2016.02.020

Wardas-Lason M (2014) The influence of sewage system on the functioning and quality of Krakow's watercourses. J Geol Res. https://doi.org/10.1155/2014/910982

Wei B, Yang L (2010) A review of heavy metal contaminations in urban soil, urban road dust and agricultural soil from China. Microchem J 94:99-107. https://doi.org/10.1016/j.microc.2009. 09.014

WHO (1993) Evaluation of certain food additives and contaminants. Techn. Rep. Ser. 837, Geneva

Yamamoto N, Takahashi Y, Yoshinaga J, Tanaka A, Shibata Y (2006) Size distribution of soil particles adhered to children's hands. Arch Environ Contam Toxicol 51:157-163. https://doi.org/10. 1007/s00244-005-7012 